\title{
Mahseer (Tor spp.) fishes of the world: status, challenges and opportunities for conservation
}

\author{
Adrian C. Pinder (D) - J. Robert Britton • Andrew J. Harrison • \\ Prakash Nautiyal $\cdot$ Shannon D. Bower $\cdot$ Steven J. Cooke $\cdot$ \\ Steve Lockett - Mark Everard • Unmesh Katwate $\cdot$ K. Ranjeet \\ Sam Walton · Andy J. Danylchuk • Neelesh Dahanukar $\cdot$ Rajeev Raghavan
}

Received: 7 November 2018/Accepted: 23 April 2019/Published online: 2 May 2019

(C) The Author(s) 2019

\begin{abstract}
The mahseer fishes (Tor spp.) represent an iconic genus of large-bodied species of the Cyprinidae family. Across the 16 recognised species in the genus, individual fish can attain weights over $50 \mathrm{~kg}$, resulting in some species being considered as premier sport fishes. Tor species also generally have high religious and cultural significance throughout South
\end{abstract}

A. C. Pinder $(\varangle) \cdot$ J. R. Britton · A. J. Harrison Faculty of Science and Technology, Bournemouth University, Poole, Dorset, UK

e-mail: apinder@bournemouth.ac.uk

A. C. Pinder - A. J. Harrison - S. D. Bower -

S. Lockett · M. Everard · R. Raghavan

Mahseer Trust, Freshwater Biological Association,

Wareham, Dorset, UK

P. Nautiyal

Department of Zoology and Biotechnology, Hemwati

Nandan Bahuguna Garhwal University, Srinagar,

Uttarakhand, India

S. D. Bower

Natural Resources and Sustainable Development Group, Uppsala University, Campus Gotland, Visby, Sweden

\section{S. J. Cooke}

Fish Ecology and Conservation Physiology Laboratory, Department of Biology, Carleton University, Ottawa, ON, Canada

\section{Everard}

University of the West England, Coldharbour Lane,

Frenchay Campus, Bristol, UK and Southeast Asia. Despite their economic and cultural importance, the status of Tor fishes has been increasingly imperilled through their riverine habitats being impacted by anthropogenic activities, such as hydropower dam construction and exploitation. Moreover, conservation efforts have been constrained by knowledge on the genus being heavily skewed

U. Katwate

Bombay Natural History Society Hornbill House, Opp.

Lion Gate, Shaheed Bhagat Singh Road, Mumbai,

Maharashtra, India

K. Ranjeet

Department of Aquatic Environment Management, Kerala

University of Fisheries and Ocean Studies (KUFOS),

Kochi, India

S. Walton

Rimba, Kuala Lumpur, Malaysia

A. J. Danylchuk

Department of Environmental Conservation, University of Massachusetts Amherst, Amherst, MA, USA

N. Dahanukar

Indian Institute of Science Education and Research

(IISER), Pune, India

R. Raghavan

Department of Fisheries Resource Management, Kerala University of Fisheries and Ocean Studies (KUFOS), Kochi, India 
towards aquaculture, with considerable knowledge gaps on their taxonomy, autecology, distribution and population status. Whilst taxonomic ambiguity has been a major constraint on conservation efforts, this has been partially overcome by recent, robust taxonomic revisions. This has enabled revision of the IUCN Red List status of Tor fishes; three species are now assessed as 'Near Threatened', one 'Vulnerable', three 'Endangered' and one 'Critically Endangered'. However, eight species remain 'Data deficient'. Here, information on these 16 Tor fishes is synthesised for the first time, outlining the current state of knowledge for each species, including their known distributions and population status. For each species, the outstanding gaps in knowledge are also identified, and their population threats and conservation prospects outlined. Consequently, this review provides the basis for researchers to challenge and enhance the knowledge base necessary to conserve these freshwater icons in an era of unprecedented environmental changes.

Keywords Freshwater fishes - Megafauna · Asia $\cdot$ Recreational angling $\cdot$ Taxonomy . Species distributions

\section{Introduction}

Global freshwater resources include a diverse fish fauna comprising close to 16,000 species (i.e. $47 \%$ of all fishes and $25 \%$ of all vertebrates), with around 250 new species described each year (Pelayo-Villamil et al. 2015; Arthington et al. 2016; Eschmeyer and Fong 2016). This diversity is, however, concentrated into limited areas ( $<1 \%$ of the Earth's surface) that are extensively exploited and modified for societal requirements (Dudgeon et al. 2006; Vörösmarty et al. 2010; Closs et al. 2016). For example, existing data suggest up to $87 \%$ of the global wetland resource has been lost since $1700 \mathrm{CE}$, with rates of loss increasing in the late twentieth century (Davidson 2014). More recent works suggest that although still covering a global area almost as large as Greenland, inland and marine/coastal wetlands have continued to decline rapidly, with $35 \%$ losses since 1970, three times the rate of global forest loss (Finlayson et al. 2018). The majority of large rivers are also now impounded (Poff and Schmidt 2016), and rivers are generally used to discharge high quantities of sewage and industrial waste (Keller et al. 2014). These stressors have resulted in freshwater fishes being among the most threatened taxa. Of approximately 7,588 species of freshwater fish assessed for the IUCN Red List, more than $20 \%$ are threatened, with 69 species already 'extinct' or 'extinct in the wild' (Darwall and Freyhof 2016).

A high proportion of fish diversity 'hot-spots' occur within countries with rapidly developing economies where protection of vulnerable habitats is of relatively low priority (Dudgeon et al. 2006; Sarkar et al. 2008; Reid et al. 2018). These hotspots include freshwaters within South and Southeast Asia that cover the native range of the mahseer, an iconic group of fishes of the family Cyprinidae (Thomas 1873; Dhu 1923; Pinder and Raghavan 2013; Nautiyal 2014). Characterised by their very large scales, these large-bodied carps (maximum recorded weight $54 \mathrm{~kg}$ (Wildlife 1977)) are currently partitioned taxonomically into the genera, Naziritor, Neolissochilus and Tor (Kottelat 2013; Froese and Pauly 2018, Eschmeyer et al. 2017). Despite some morphological similarities across these fishes, it is only those species of the genus Tor that are considered the 'true mahseers' (Desai 2003; Nguyen et al. 2008) and which form the focus of this review. This genus currently comprises 16 valid species (Table 1), all of which are considered to exhibit highly potamodromous behaviours, with upstream spawning migrations, often over 'considerable' distances, reported as being necessary to facilitate successful reproduction (Nautiyal et al. 2001, 2008; Shrestha 1997).

The high nutritional value of Tor mahseer (Day 1876) and their ability to provide food security in regions with high poverty levels means that reports of their high exploitation date back to the nineteenth century (Thomas 1873). More recently, in many Asian countries, combinations of major river engineering projects, declining water quality and other anthropogenic impacts (e.g. invasive species) are resulting in Tor mahseers facing unprecedented population pressures (Dudgeon 2011; Grumbine and Pandit 2013). Despite their high economic and cultural importance (Nautiyal 2014), population level data across the Tor genus remain severely limited, with fundamental aspects of their biology and autecology unknown for most species (Raghavan 
Table 1 List of currently valid mahseer (Tor spp.), distribution and conservation status as per the IUCN Red List of Threatened Species $^{\mathrm{TM}}(*$ Version 2018.2)

\begin{tabular}{|c|c|c|c|c|c|}
\hline Valid species name & Common name(s) & Synonyms & Distribution & $\begin{array}{l}\text { IUCN } \\
\text { previous } \\
\text { status }\end{array}$ & $\begin{array}{l}\text { IUCN } \\
\text { current } \\
\text { status* }\end{array}$ \\
\hline $\begin{array}{l}\text { Tor ater (Roberts } \\
\text { 1999) }\end{array}$ & & & Laos & VU & NT \\
\hline $\begin{array}{l}\text { Tor barakae } \\
\quad \text { (Arunkumar and } \\
\text { Basudha 2003) }\end{array}$ & Barak Mahseer & & India & $\mathrm{NE}$ & NT \\
\hline $\begin{array}{l}\text { Tor dongnaiensis } \\
\quad \text { (Hoang et al. } \\
\text { 2015) }\end{array}$ & Dongnai Mahseer & & Vietnam & & NT \\
\hline $\begin{array}{l}\text { Tor khudree (Sykes } \\
1839)\end{array}$ & Deccan mahseer & Barbus longispinis, Tor neilli & India & EN & EN \\
\hline $\begin{array}{l}\text { Tor kulkarnii } \\
\quad \text { (Menon 1992) }\end{array}$ & Dwarf mahseer & & India & EN & DD \\
\hline $\begin{array}{l}\text { Tor laterivittatus } \\
\text { (Zhou and Cui } \\
\text { 1996) }\end{array}$ & & & China, Laos & DD & DD \\
\hline $\begin{array}{r}\text { Tor malabaricus } \\
\text { (Jerdon 1849) }\end{array}$ & Malabar mahseer & & India & EN & EN \\
\hline $\begin{array}{l}\text { Tor mosal } \\
\quad \text { (Hamilton 1822) }\end{array}$ & $\begin{array}{l}\text { Mosal mahseer, } \\
\text { Copper mahseer }\end{array}$ & Barbus megalepis & India, Myanmar & $\mathrm{NE}$ & DD \\
\hline $\begin{array}{l}\text { Tor polylepis (Zhou } \\
\text { and Cui 1996) }\end{array}$ & & & China & DD & DD \\
\hline $\begin{array}{l}\text { Tor putitora } \\
\quad \text { (Hamilton 1822) }\end{array}$ & $\begin{array}{l}\text { Putitor mahseer, } \\
\text { Himalayan mahseer, } \\
\text { Golden mahseer }\end{array}$ & $\begin{array}{l}\text { Barbus microcephalus, Tor } \\
\quad \text { macrolepis, Tor mosal } \\
\text { mahanadicus, Tor progeneius }\end{array}$ & $\begin{array}{l}\text { Afghanistan, Bangladesh, } \\
\text { Bhutan, India, Myanmar, } \\
\text { Nepal, Pakistan }\end{array}$ & EN & EN \\
\hline $\begin{array}{l}\text { Tor remadevii } \\
\text { (Kurup and } \\
\text { Radhakrishnan } \\
\text { 2007) }\end{array}$ & Hump-backed mahseer & & India & & $\mathrm{CR}$ \\
\hline $\begin{array}{l}\text { Tor sinensis }(\mathrm{Wu} \\
1977)\end{array}$ & Red mahseer & & China, Vietnam, Laos & DD & VU \\
\hline $\begin{array}{l}\text { Tor tambra (Cuvier } \\
\text { and Valenciennes } \\
1842)\end{array}$ & & $\begin{array}{l}\text { Puntius streeteri, Tor douronensis, } \\
\quad \text { Tor mekongensis }\end{array}$ & Indonesia, Malaysia & DD & DD \\
\hline $\begin{array}{l}\text { Tor tambroides } \\
\quad \text { (Bleeker 1854) }\end{array}$ & & & Indonesia, Malaysia & DD & DD \\
\hline $\begin{array}{l}\text { Tor tor (Hamilton } \\
\quad \text { 1822) }\end{array}$ & $\begin{array}{l}\text { Tor mahseer, Red-fin } \\
\text { mahseer, Deep- } \\
\text { bodied mahseer }\end{array}$ & Tor barakae, Tor hamiltonii & $\begin{array}{l}\text { Bangladesh, Bhutan, India, } \\
\text { Myanmar, Nepal, Pakistan }\end{array}$ & NT & DD \\
\hline $\begin{array}{l}\text { Tor yingjiangensis } \\
\text { (Chen and Yang } \\
\text { 2004) }\end{array}$ & & & China & & DD \\
\hline
\end{tabular}

IUCN Red List status key: $N E$ not evaluated; $L C$ least concern; $N T$ near threatened; $V U$ vulnerable; $E N$ endangered; $C R$ critically endangered; $D D$ data deficient $*$ Version 2018.2 


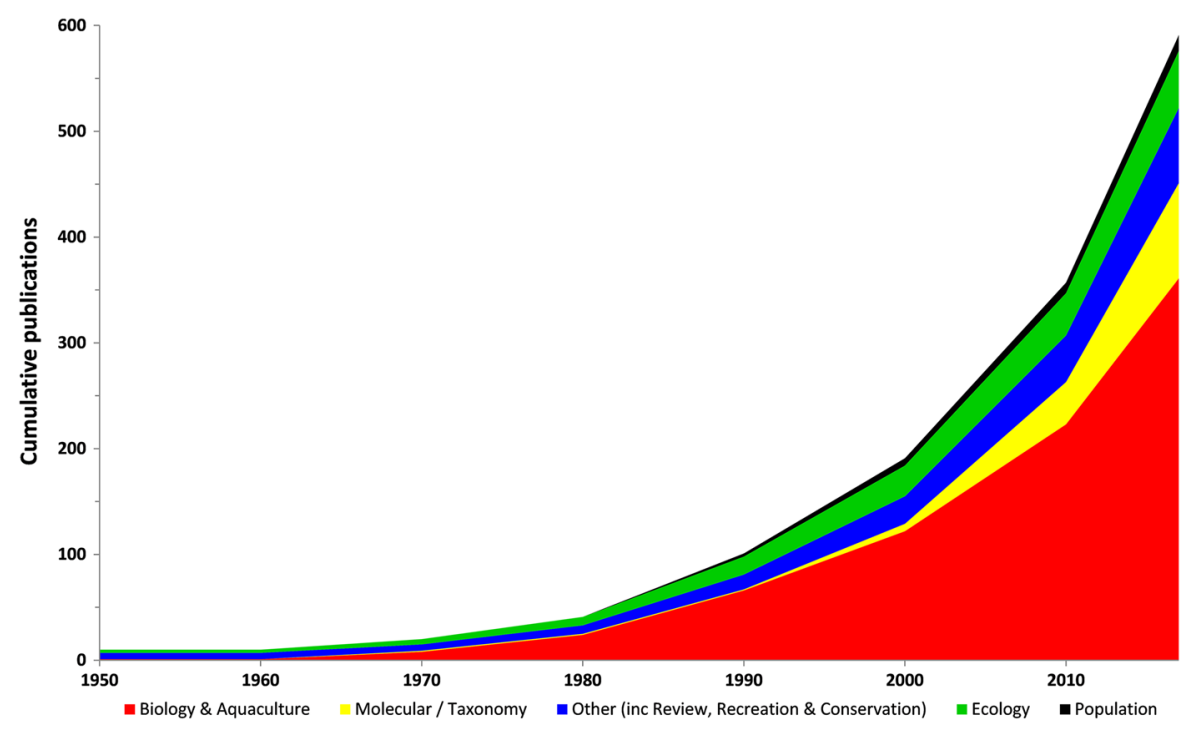

Fig. 1 Cumulative publications by subject area from 1950 to 2017. Based on a Google Scholar search ["tor mahseer", all words, anywhere in article]. First 1000 search results manually filtered to remove duplicates and retain relevant publications only $(n=591)$. Each publication was categorised into one of

et al. 2011; Pinder and Raghavan 2013; Bhatt and Pandit 2016). Whilst research efforts on the genus have accelerated in recent years (Fig. 1), this has been heavily skewed towards aquaculture (Kumar et al. 2013; Norfatimah et al. 2014; Raman et al. 2016).

While some of these studies provide strong contributions to the Tor taxonomic knowledge base (Hora 1939; Roberts 1999; Walton et al. 2017), many fail to reference original species descriptions, type localities and lack the integration of morphological data that would assist field biologists (Nguyen et al. 2008; Mani et al. 2009). Furthermore, with frequent evidence of the 'blind' propagation of repetition and errors in citation networks (see Greenberg 2009), many studies (for e.g. Laskar et al. 2013; Khare et al. 2014) have only resulted in further taxonomic confusion across the genus.

With interest to conserve this group of iconic fishes growing rapidly across multiple stakeholder groups (e.g. scientists, conservationists, recreational anglers, land and water resource managers) (WWF 2013; Bower et al. 2017), there is an immediate urgency to provide practitioners, regulators and policy-makers with standard points of reference to benchmark the current state of knowledge and conservation status of the genus Tor. Consequently, by synthesising the literature of Tor fishes, the five subject areas (Biology and Aquaculture, Molecular/ Taxonomy, Population, Ecology or Other [including Review, Recreation and Conservation]), based on the main theme of the publication

objectives of this paper are to: (1) highlight the importance of the fishes of the genus Tor in Asia with respect to religion and society; (2) clarify the validity and taxonomic identity of species included within the Tor genus; (3) provide the geographic distribution of each Tor species based on current understanding and uncertainties, and outline their population threats and species' extinction risks; and (4) identify the prioritised research and conservation needs, and actions for policy makers. With specific reference to Objective 3, we present a revised conservation status of 16 valid species of which each has been recently assessed (four for the first time) or re-assessed against IUCN Red List categories and criteria (IUCN 2012, 2017). This has resulted in eight species being assessed as Data Deficient, three as Near Threatened, one as Vulnerable, three as Endangered and one as Critically Endangered (Table 1).

\section{Role in history religion and culture}

Whether due to their large body size and/or attractive appearance, mahseer fishes have long been afforded saintly status as 'God's fishes' across their biogeographic range, being revered amongst isolated tribal societies (Gupta et al. Gupta et al. 2016). Paintings 
depicting large-scaled fish on Nal pottery, from the Baluchistan region of Pakistan, indicate an interest in these fishes as early as $3000 \mathrm{BC}$ (Hora 1956). Other archaeological studies of the same geographic area and era have recorded bones of freshwater fishes, but not those of mahseers. This suggests that although fish represented a staple part of the diet of the Indus Valley Civilisation (Belcher 1998), mahseer were not consumed due to their high cultural value.

References describing sacred and masculine figures of 'mahseer-like' fish can also be found in Hindu religious scriptures, symbols, motifs, sculptures, and in ancient literature (Jadhav 2009; Nautiyal 2014). The accounts on Vishnu's first incarnation as the fish "Matsya", symbolized in the form of zoomorphic and anthropomorphic sculptures, are commonly found in ancient temples throughout India. At many religious temples nestled along river banks throughout India, adjacent pools have been afforded protection from exploitation for centuries and, outside of the monsoon season, these support dense accumulations of mahseer (Dandekar 2011a, b; Gupta et al. 2016). These community-protected areas, often described as 'temple sanctuaries' or 'temple pools', are safeguarded through the social beliefs and sentiments of devotees, and the participatory approach of villagers and temple authorities (Sen and Jayaram 1982; Gadgil 1991; Bhagwat and Rutte 2006; Dandekar 2011a; Katwate et al. 2014). Although the exact number of community-protected fish areas within India is unknown, the state of Karnataka has at least 17 sanctuaries, with Uttarakhand also reported to have a large number of protected sites (Dandekar 2011b). These numbers are likely to be substantial underestimates, as personal observations of the authors have witnessed numerous pools alongside small tributary streams that are adjacent to temples. Although such community-protected areas provide an example of effective in situ conservation action, the migratory behavior of these fishes suggests that these need to work alongside catchment-scale habitat management and harvest regulation in order to promote selfsustaining populations.

Paradoxically, there are also examples of where temple sanctuaries have exposed mahseer populations to elevated risk from degraded environmental conditions. For example, large congregations of Deccan mahseer (Tor khudree) near the temples of Alandi and Dehu on the Indrayani River and Pandharpur on
Bhima River, Maharashtra, have been killed via major pollution events, with the fish unable to escape the pollutants due to their captive habitat (Sen and Jayaram 1982). Other authors have also highlighted the risks posed to temple pools by the upstream construction of hydroelectric dams that subject the stocks to abrupt changes in flow regime (Dandekar 2011b) and block access to spawning habitat (Everard 2013). The intentional destruction of an entire stock of mahseer from a temple pool in River Kapila, Karnataka has also been reported when fishermen who had previously been prosecuted for illegally harvesting the fish, returned and deliberately poisoned the remaining fish in an act of sabotage (Jayaram 1997).

The strength of Tor mahseer has also been recognised in ancient Indian culture, with a record highlighting the recreational value of 'such big sized fishes' from the early twelfth century (Hora 1951; Jadhav 2009; Nautiyal 2014). In 1127-1138 AD, the King of Western Chalukya, King Someshvara III, authored a compendium in Sanskrit "MansollasaMānasollāsa" (meaning the "refresher of the mind"). This referred to 35 different species of marine and freshwater sport fishes, each with unique name (Sadhale and Nene 2005; Jayaram 2005). Within these works, the riverine game fish called 'Mahashila' is described as a 'riverine scaly large fish'. Mahashila in Sanskrit means a large stone-like (powerful) fish, and is thought to refer to the mahseers (Hora 1953; Sadhale and Nene 2005). There are, however, contradictory views among researchers regarding the exact species of mahseer to which this refers (Hora 1953; Sadhale and Nene 2005). Indeed, during the rule of Someshvara III, the Empire of Western Chalukya was confined to the current geographical areas of Andhra Pradesh, Karnataka, and Maharashtra states, meaning that the fish could have been any one or a combination of Tor species found in Southern India. In his compendium, King Someshvara III also provided discussion on angling techniques, selection and use of fishing rod, rope, different kind of fish baits and their preference to the wide array of fish types. This also provided robust evidence that the art of recreational angling was practiced in ancient India since the early twelfth century (Hora 1953; Sadhale and Nene 2005; Nautiyal 2014). 


\section{Population threats}

The regions in the developing world in which mahseers occur are subject to spiralling resource demands from a rapidly growing and industrialising population. In examining trends in large-scale hydrological changes across Asia, Dudgeon (2000) highlighted four principal threats to freshwater fishes: flow alteration and regulation (e.g. dam construction and abstraction), pollution, drainage basin alteration (e.g. deforestation), and over-harvesting. Each of these categories is highly relevant to threats to the population status of Tor species (Raghavan et al. 2011; Bhatt and Pandit 2016; Everard et al. 2018).

With specific focus on India, the World Bank (2018) recorded a 1.2\% annual economic growth rate and a near doubling of energy use between 2000 and 2015. These rising demands place significant pressures on water resources, including the harnessing of river water for domestic, industrial, irrigation and electricity generation purposes. India has a long history of hydropower development with, for example, the hydroelectric power plants constructed at Darjeeling (West Bengal) and Shivanasamudram (Karnataka) at the turn of the twentieth century being among the first in Asia (Ullah 2015). Rivers are also regularly harnessed for water supply purposes, routing river flows by canals and pipes from areas of perceived excess to those of higher demand (World Commission on Dams 2000). To support these spiralling water and energy demands, India has developed a high dependence on large dams, with 4877 completed and 313 more under construction (CWC 2017). Development of large-scale hydropower schemes has also increased across other mahseer range countries, with dams typically impounding rivers in the higher topography landscapes that constitute prime habitat for Tor spp. (Shrestha 1997; Nautiyal 2014; Bhatt and Pandit 2016).

The multiple environmental and social impacts of dams are complex but include the compromised movement of diadromous and potamodromous fishes, which can often deny access to optimal-sometimes critical—spawning habitats (Ferguson et al. 2011). Modified flow rates, habitat structure and limited sediment transport also result in progressive erosion, depletion of lithophilic spawning substrates and invasion of novel macrophytes in affected downstream lotic reaches (Poff et al. 2007; Johnson et al. 2008; Poff and Zimmerman 2010; Poff and Schmidt 2016). Ecosystems are further perturbed by simplification of habitat hydrology, often with excess macrophyte growth in the littoral zone, and the colonisation of invasive species in the water and also in the riparian zone (De Jalon et al. 1994). Indeed, the simpler habitat structure and changed hydrology of impounded rivers increases their vulnerability to alien invasive species (Johnson et al. 2008; Quinn and Adams 1996).

With particular relevance to environmental policy designed to protect Indian biodiversity and habitats, freshwater fish are excluded from definitions of "wild animals' and from inclusion in any of the schedules of the India's Wildlife Protection Act 1972 (Pinder and Raghavan 2013). The net result is that there is minimal responsibility on developers to incorporate fish passage or mitigation into dam construction (Theophilus 2014). Indeed, the consequences of river impoundments on native aquatic biodiversity appear to have been overlooked in favour of the perceived positive benefits of the 'clean' contribution of hydropower to energy deficits and the potential for large lentic waterbodies to enhance fisheries potential (particularly of non-native species) to contribute to nutritional food security (Sharma 1987). This is important, as the continuing construction of dams is resulting in increased impoundment and loss of longitudinal connectivity that is assumed to impact the natural movements of Tor spp., such as spawning migrations (Shrestha 1997; Nautiyal 2014; Bhatt and Pandit 2016).

In the tropical regions inhabited by mahseer, the creation of large expanses of lacustrine habitat also results in high levels of evaporation, which can result in substantial water losses. This reduces the dilution potential of pollutants, further threatening the maintenance of ecologically acceptable flows to support the various life history stages of Tor spp., as well as compromising the quantity of water available for human use (e.g. consumption and irrigation) (Everard et al. 2018).

Invasive aquatic species are a pervasive problem across South and Southeast Asia (Johnson et al. 2008; Peh 2010; Dudgeon 2011). These include fish that may directly compete with mahseer, or other flora and fauna which impact indirectly by disrupting ecological function (Gupta and Everard 2017). 
Related to this issue, the stocking of captive-reared mahseers, particularly non-indigenous species, has been shown to not only threaten the integrity of ecosystem function, but also threaten the extinction of endemic mahseer species (Pinder et al. 2015b). Further pressure arises from direct exploitation of mahseer stocks beyond natural regeneration rates. This age-old issue, first reported by Thomas (1873) and Dhu (1923), is compounded by contemporary unsustainable fishing methods, such as indiscriminate gill-netting, dynamiting and poisoning (Raghavan et al. 2011), and particularly when mahseer stocks are at their most vulnerable when concentrated in summer pools and/or ascending small tributaries during the spawning migration (Everard and Kataria 2011).

A range of other anthropogenic stressors then further exacerbates these population pressures that primarily relate to human population growth and its upward resource demands, including from industrialisation and intensive farming. Although population growth and resource demands are typically focused on India, throughout Asia as a whole, poverty of resources and poor education is also resulting in people over-exploiting natural resources such as fisheries to fulfil immediate needs, rather than stewarding them for the longer term (Smith et al. 2005). Climate change is a significant additional pressure, with direct impacts on the drying out of springs in the middle Himalayas that constitute important spawning areas (ICIMOD 2009). There is also a trend towards increased river flow variability and river runoff in pre-monsoon months, potentially leading to a higher incidence of unexpected droughts and floods with widespread consequences for climate-dependent sectors such as agriculture, water resources and health (Shrestha et al. 2015).

\section{Taxonomic challenges}

Despite the first mahseer species being described in 1822 (Hamilton 1822) and methodical investigations on the taxonomy, nomenclature and systematics starting in the early twentieth century (e.g. Hora 1939), some taxonomic ambiguity remains across the Tor genus (Pinder and Raghavan 2013). Original descriptions of many mahseer species are vague and finding standard diagnostic characters to distinguish species has been difficult (Walton et al. 2017). In addition, the mahseer literature of the twentieth century, particularly descriptions and illustrations available in species accounts, are inconsistent and highly variable, increasing the likelihood of misidentifications. Published evidence on range limits has also been highly confusing and contradictory, and authentication of such information has now become impossible due to the absence of accompanying voucher specimens ( $c f$. Walton et al. 2017). The quantity of taxonomic literature is also not an indication of its quality and tends to increase confusion further (Fig. 1). Many recent studies on mahseer taxonomy have not referred to original descriptions and have uncritically relied on compilations and published papers (for a discussion see Raghavan et al. 2017).

Tor are tetraploid (Arai 2011) and possess 100 diploid chromosomes (Mani et al. 2009). Such polyploid taxa therefore pose significant challenges for interpretation of phylogenetic data. Many of the phylogenetic studies carried out on the Tor mahseer have focused on the mitochondrial $\mathrm{CO} 1$ gene, whilst others have used nuclear markers but without understanding the issue of paralogy associated with polyploid taxa (Yang et al. 2015). Nuclear genes are expected to have two copies in tetraploid taxa and these different gene copies can be quite divergent and belong to distinct clades in a phylogenetic tree ( $c f$. Evans et al. 2005; Saitoh et al. 2010; Yang et al. 2015). Therefore, the results of several phylogenetic studies undertaken on Tor mahseer to date are considered to be misleading and should be treated with caution.

Issues with historic and current literature on mahseer taxonomy are further exacerbated with the unique morphological variations that mahseer fishes exhibit. As a group, mahseer exhibit considerable phenotypic plasticity, including intra-specific morphological variation, trophic polymorphism, and sexual dimorphism, making precise, morphologically based identifications extremely difficult (Walton et al. 2017). For example, whilst many previous workers have used diagnostic characteristics such as the shape, size and length of the median lobe (the key diagnostic character of the genus), as well as body colour, to distinguish Tor species, these characteristics are known to be highly variable within species (Roberts 1999; Menon 1992). This variability has been attributed to environmental influences, habitat 
changes (Hora 1939; Esa et al. 2006) and trophic polymorphism (Walton et al. 2017). Despite this, there have been very few studies that have explored how this plasticity contributes to the observed diversity of morphologies in mahseers. Whilst Roberts and Khaironizam (2008) attempted to examine these relationships, their observations were based on a polymorphic population of a Neolissochilus species and not of a Tor species (Walton et al. 2017).

Commensurate with the publication of this paper, the IUCN Red List of Threatened Species ${ }^{\mathrm{TM}}$ has published revised assessments of all mahseers currently considered as valid species within the Tor genus. Table 1 lists the currently valid species, their endemism, common names, synonyms and current/ previous Red List status. Despite considerable recent advances in knowledge, the taxonomy and conservation status across the Tor genus remain dynamic. For example, eight species have been assessed as 'Data Deficient' due to a paucity of currently available data to assess their extinction threat. A summary of the taxonomy and revised Red List assessment status is provided for each species under individual species summaries.

\section{Individual species summaries}

With reference to the key aims stated in the introduction, the purpose of the following species summaries is to (1) clarify the validity and taxonomic identity of species included within this genus (Table 1); (2) provide the geographic distribution of each Tor species based on current understanding and uncertainties; and (3) briefly summarise the evidence informing current IUCN Red List assessment status, inclusive of population threats and extinction risk. Individual species summaries, with varying levels of available detail, are presented in alphabetical order by scientific name, as listed in Table 1 .

\section{Tor ater}

Described from Nam Theun at Ban Talang, Central Laos (Roberts 1999) (Fig. 2), T. ater is characterised by its relatively small scales and dark fins, with adults and sub-adults also exhibiting a dark mid-lateral band of pigment. The entire distribution range of this species falls within the Nakai National Biodiversity
Conservation Area in Laos, having only been recorded from two streams in the upper Nam Theun catchment, with definitive records only from the Nam Xot and the Nam Theun, located upstream of the Nam Theun 2 Dam (Kottelat 2016; Kottelat et al. 2012). Although lacking any scientific information on population status, T. ater is considered, based on local knowledge, as a rare species but does feature in the catch of local subsistence fishers. Overfishing and the relatively recent fragmentation of habitat by the construction of the Nam Theun Dam in 2010 are key threats to the species, which has been assessed as Near Threatened (Kottelat et al. 2018a).

\section{Tor barakae}

Tor barakae, described from the Barak River, Manipur, India (Arunkumar and Basudha 2003), was considered a questionable synonym of $T$. tor (Kottelat 2013) until recent research by Laskar et al. (2018) clarified the validity of the species, and distinguished it from co-occurring $T$. putitora by a relatively short head-length to body-depth ratio. Although not compared against $T$. tor from the type locality, the same relative features also reliably separated T. barakae from T. tor collected from the Central Indian Narmada system. Available photographs from the type locality display a deepbodied Tor with a relatively small terminally positioned mouth and fins of red and blue colouration. This species is endemic to the Barak River, having been recorded from the streams near Vanchengphai, and Makru in Manipur, and from Madhpur on the Manipur-Assam border (Arunkumar and Basudha 2003; Laskar et al. 2018) (Fig. 3). Tor barakae is poorly-known with no information on the population, biology and micro-level distribution. Available information on the restricted distribution of the species and threats to the habitat has led to it being assessed as Near Threatened on the IUCN Red List (Vishwanath et al. 2018).

\section{Tor dongnaiensis (and T. mekongensis)}

Two species, Tor dongnaiensis and T. mekongensis were recently described from the Upper Krong No and middle Dong Nai basins in Southern Vietnam (Hoang et al. 2015). While T. dongnaiensis has been assessed as Near Threatened on the IUCN Red List 


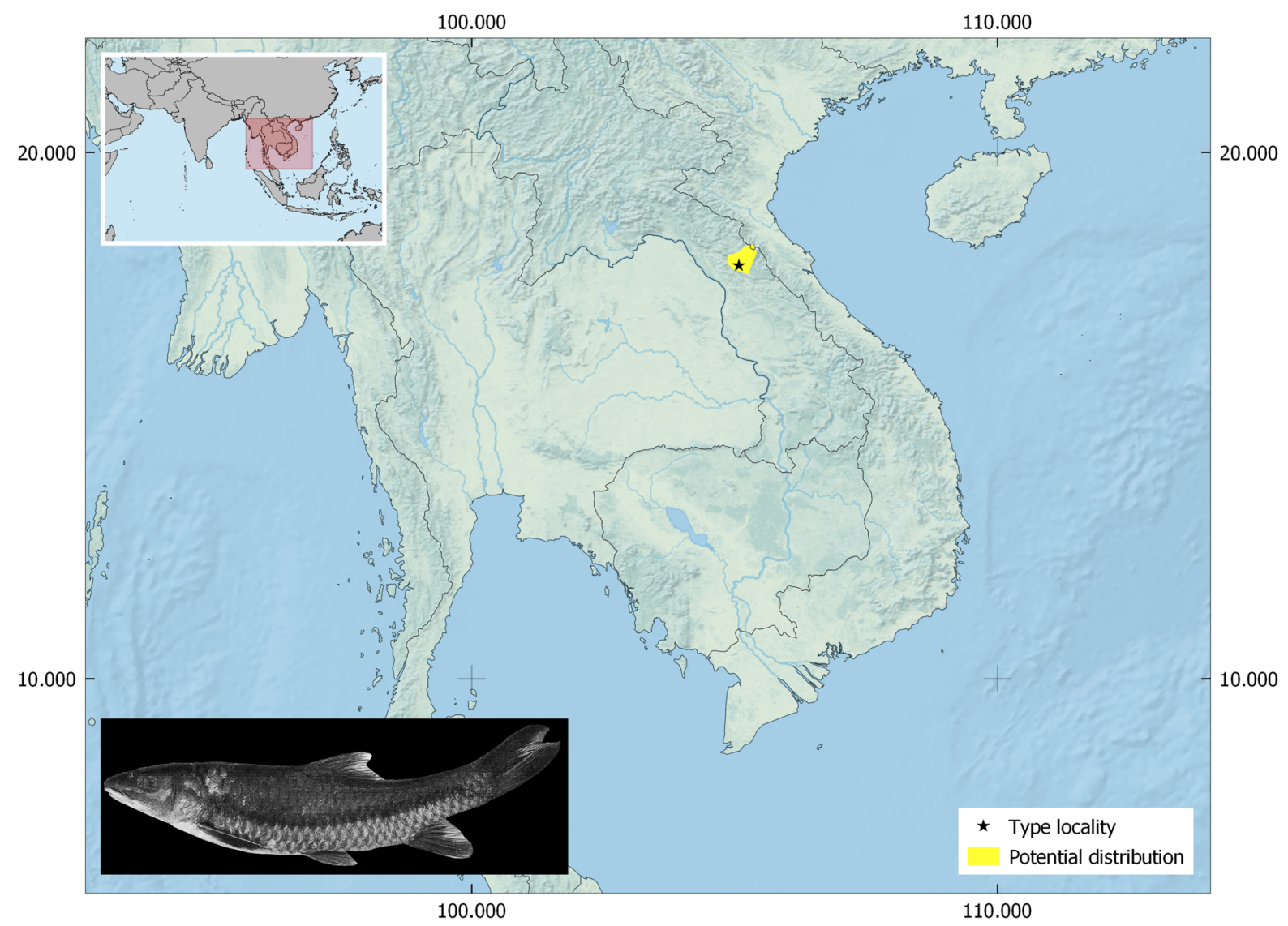

Fig. 2 Distribution of Tor ater. Inset image: T. ater holotype (308 mm) from the Nam Theun at Ban Talang, Laos. With kind permission of T. Roberts

(Version 2018-2) due to its apparent restricted distribution (Pinder and Harrison 2018) (Fig. 4), T. mekongensis is currently considered to be a questionable synonym of the wide-ranging T. tambra (see Walton et al. 2017). Further taxonomic studies are required on both these species of Vietnamese mahseers by including and comparing them to a larger sample/dataset of Tor species from other parts of South East Asia.

\section{Tor khudree}

British naturalist W. H. Sykes described Tor khudree from the 'Mota Mola River, approximately eight miles to the east of Poona' (=Mula-Mutha River in the current day Pune, Maharashtra, India) (Sykes 1839) (Fig. 5). The species epithet was most likely derived from the local name of the species 'Khudis or Khadshi' in Marathi Language (Sykes 1839). The original description was laconic, with an extended description later offered by Sykes (1841) still lacking an illustration or details of any type material. For the next one hundred years (from 1849 to 1940), several workers presented contrasting opinions regarding the identity and taxonomic status of this species. Hora (1942, 1943) was the first to resolve the identity of $T$. khudree, re-describing the species based on specimens (and illustrations) collected from the type locality. Although the first genetic characterization of this species was provided by Nguyen et al. (2008), the local extirpation of $T$. khudree from the type locality (Wagh and Ghate 2003; Kharat et al. 2003) dictated that genetic material had to be sourced from fish originating from artificially propagated stocks known to have been introduced, and successfully established populations in reservoirs in Maharashtra and Kerala (see Ogale 2002). 


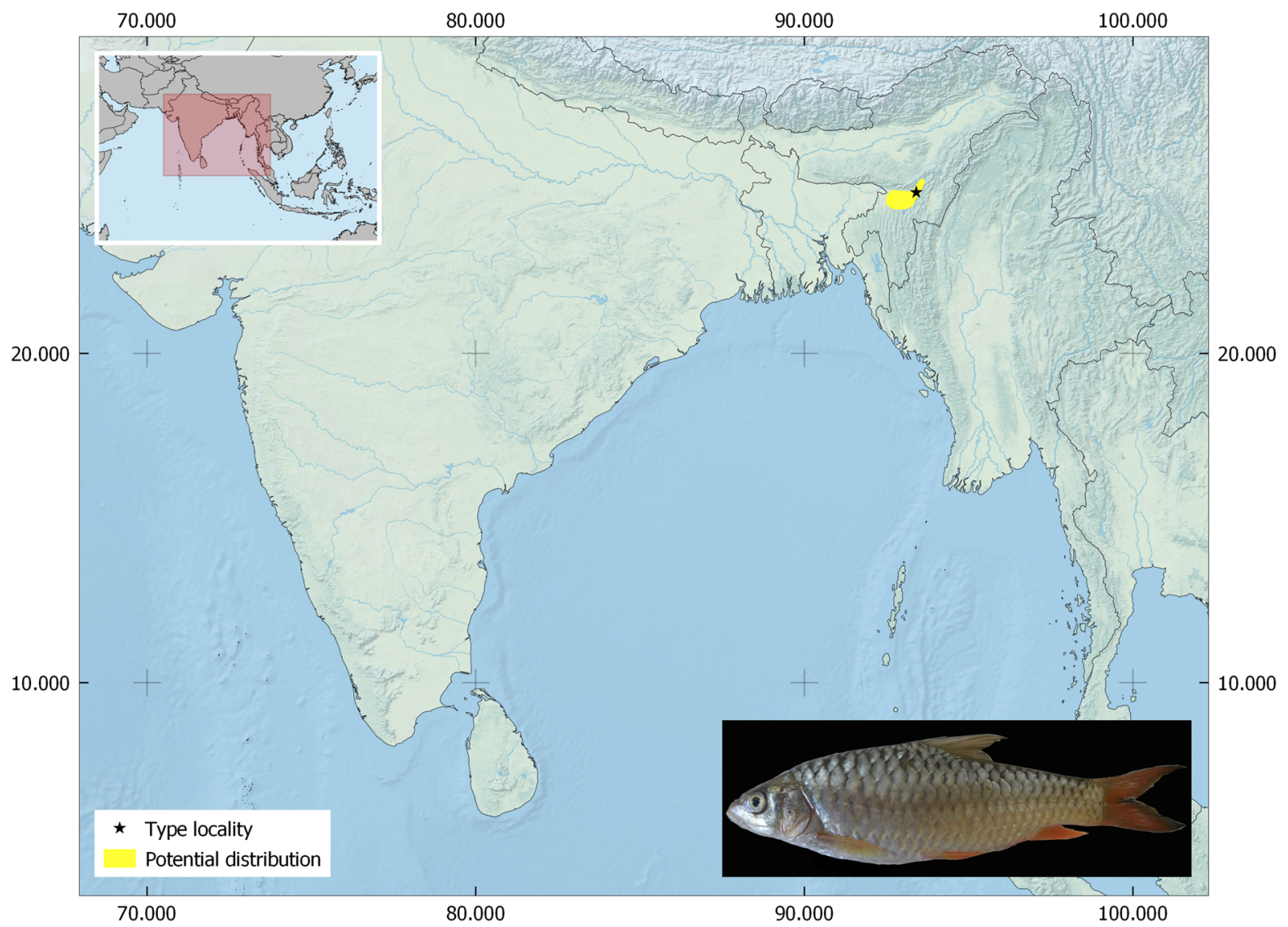

Fig. 3 Distribution of Tor barakae. Inset image: T. barakae $(405 \mathrm{~mm})$ from the Barak River, Manipur, India. With kind permission B. Amin-Laskar

All available evidence suggests that the historic distribution range of $T$. khudree was limited to the northern and Central Western Ghats (current day Maharashtra, Telengana and Karnataka states) in the eastward flowing Krishna River system including its tributaries, the Indrayani, Mula Mutha, Koyna, Krishna, Tungabhadra and Panchaganga (Sykes 1841; Hora 1942, 1943). However, the species is currently known to be distributed throughout peninsular India, particularly in the westward flowing river systems originating from the southern Western Ghats (Menon 1992; Jayaram 1995, 2005). Since the early 1970s, artificial propagation and national stocking augmentation policy has resulted in a dramatic expansion of the natural biogeographic range of $T$. khudree, with large numbers of fingerlings having been distributed to every state in India, with a further record, predating 2002, of 1500 T. khudree fingerlings being shipped and introduced to Laos (Ogale 2002).
Some of these introduced populations in India are now known to be thriving and demonstrating invasive characteristics by limiting populations of endemic fishes, including other species of Tor (Pinder 2015; Pinder et al. 2015b). Tor khudree has been assessed as Endangered due to continuing decline in the overall population (Raghavan 2013). However, it is to be noted that beyond the Krishna drainage, T. khudree is now considered non-indigenous and in some cases (e. g. River Cauvery) invasive and detrimental to endemic aquatic biodiversity (Pinder 2015; Pinder et al. 2015b).

\section{Tor kulkarni}

Tor kulkarnii (Fig. 6) was described as a dwarf cognate of $T$. khudree from the Dharna River at Deolali, a tributary of the River Godavari in Maharashtra, India (Menon 1992), but subsequently 


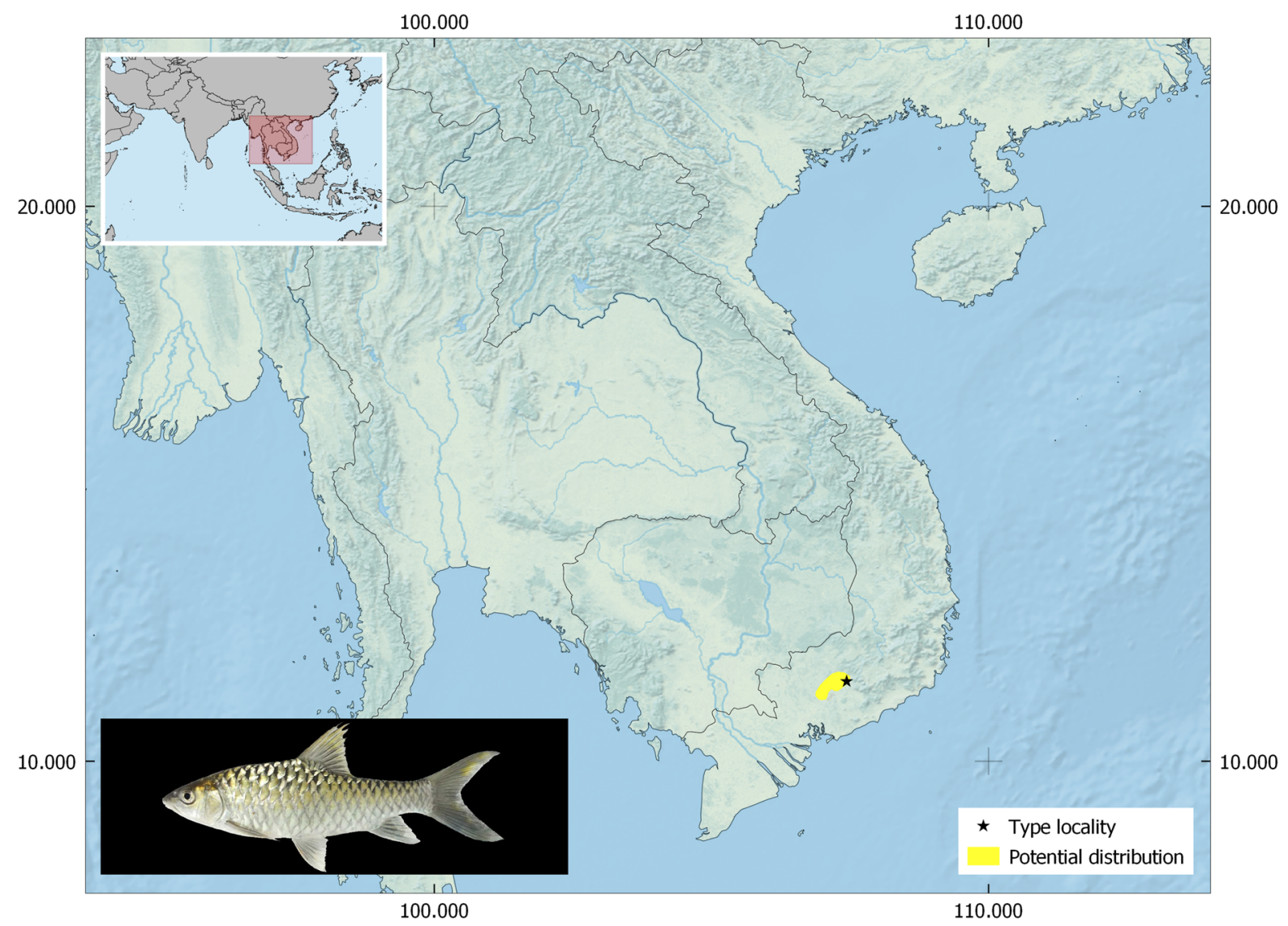

Fig. 4 Distribution of Tor dongnaiensis. Inset image: T. dongnaiensis $(240 \mathrm{~mm})$ from the Đồng Nai River, Vietnam. With kind permission of Huy Duc Hoang

considered as a synonym of $T$. khudree (Jayaram 1999, 2005, 2010). Interestingly, there are no confirmed records of the species backed by voucher specimens or photographs after its description. The species is known from only a single location in the upper reaches of the Godavari River system (Darna River at Deolali, Nashik District, Maharashtra) (Fig. 11) and not from the Krishna River system, as is mistakenly indicated in a distribution map provided by Menon (2004). Despite noting that the species is remarkably similar to T. khudree (Dahanukar 2011), subtle yet statistically significant variations in body morphology (e.g. ratio of head length vs. standard length) have seen $T$. kulkarni accepted as a valid species. The taxonomic status of this species is, therefore, likely to be secure until molecular evidence from the type locality is available (if the fish is still present) to confirm or dismiss taxonomic validity. In the absence of any other information apart from its type locality and type material, the species is assessed as Data Deficient (Dahanukar et al. 2018a).

\section{Tor laterivittatus}

Tor laterivittatus was described from the Nanla tributary of the Lancang Jiang in Yunnan Province (Zhou and Cui 1996) and is known to occur in the Mekong basin in China (Yunnan), Lao PDR (Xe Kong drainage) and Thailand (Kottelat 2001) (Fig. 7). Like many mahseer known from China, T. laterivittatus is poorly-studied species and much of the information has been generated outside China (in Laos) and through local knowledge of fishers. This species is known to be threatened by overfishing, especially where dynamite and illegal nets are used. Logging, deforestation, agriculture and hydropower dams represent additional threats. The current 


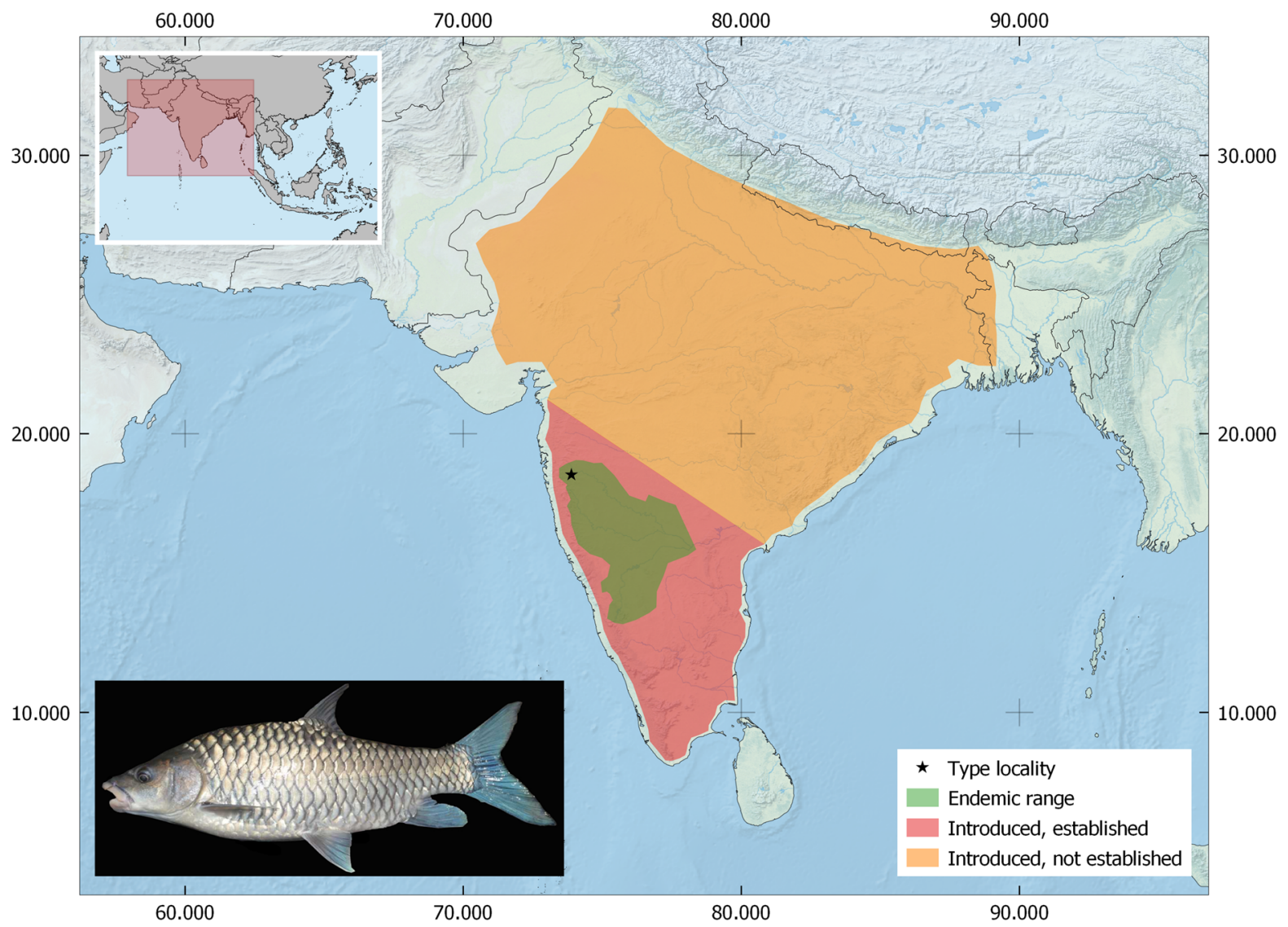

Fig. 5 Distribution of Tor khudree. Inset image: T. khudree $(520 \mathrm{~mm})$ from the River Cauvery and believed to be the progeny of hatchery stocks introduced from Lonavla,

conservation status of the species is Data Deficient (Kottelat 2018).

\section{Tor malabaricus}

The Malabar mahseer, Tor malabaricus, was described from the mountain streams of Malabar (an erstwhile province of Southern India; currently in the northern part of Kerala State), India (Jerdon 1849). The species had a confusing taxonomy, as some authors considered it a synonym of the Deccan mahseer, T. khudree (Menon 1992; 1999), while others believed it to be a valid sub-species, T. khudree malabaricus (Indra 1993). Known to be endemic to the Western Ghats region (part of the Western GhatsSri Lanka Biodiversity Hotspot), the species has been recorded from the upper and middle reaches of westward flowing rivers in the states of Karnataka,
Maharashtra, India. Note: delineation of 'introduced, established' and 'introduced, not established' is approximate only

Kerala and Tamil Nadu (Fig. 8). In at least two rivers in Kerala, T. malabaricus are known to coexist with introduced populations of T. khudree (Raghavan and Ali 2013). It forms the target of subsistence fisheries by local communities in all major river systems in which they occur. Although levels of offtake are not very high, the life history traits of the species ( $K$ selective) coupled with increasing anthropogenic stressors in their habitats, including habitat loss due to hydropower dams and reservoirs, pollution from multiple sources and sand mining, the species has been assessed as Endangered (Raghavan and Ali 2013).

\section{Tor mosal}

Much confusion has surrounded the identity and distribution of the mosal or copper mahseer, T. mosal 


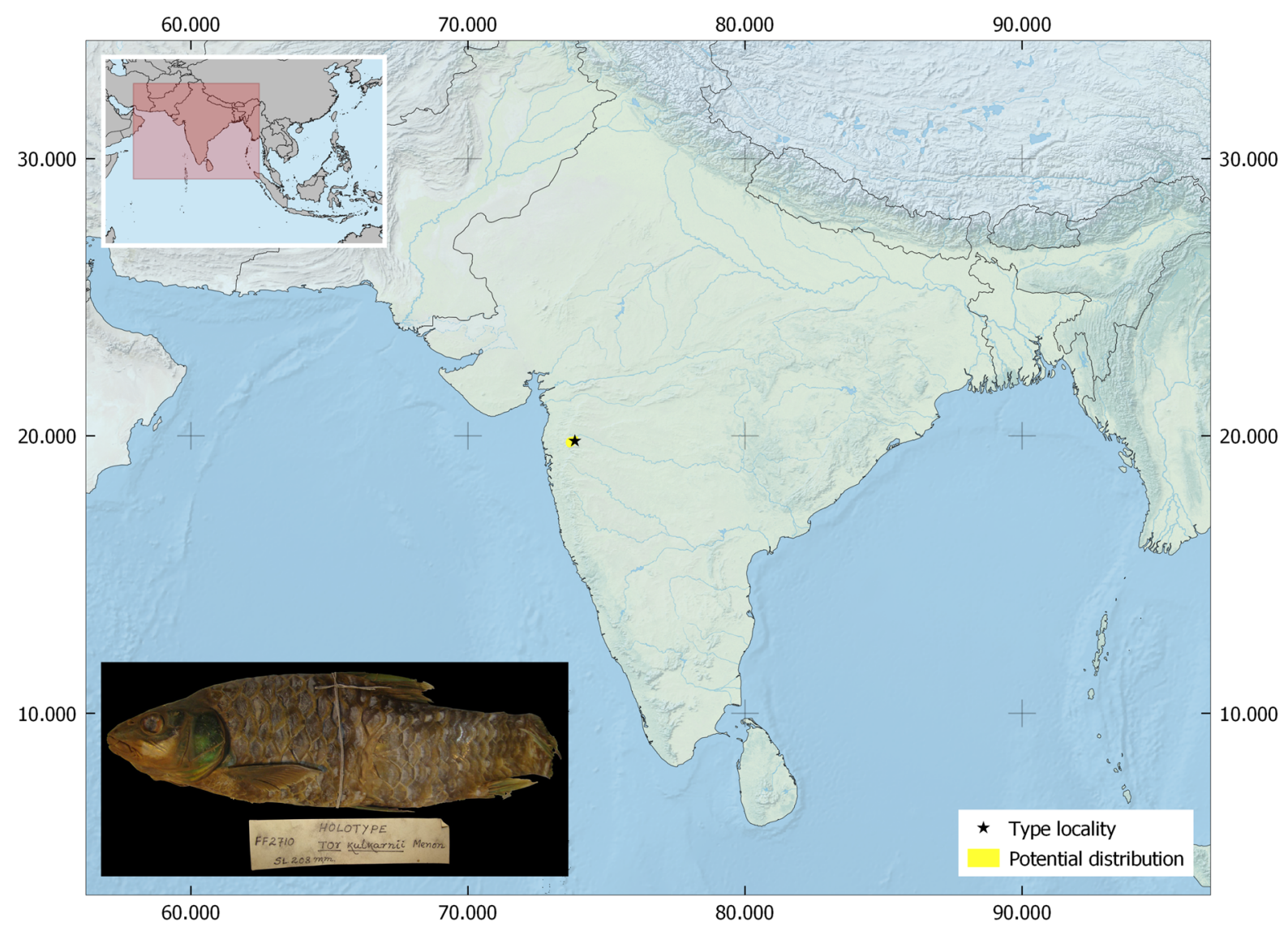

Fig. 6 Distribution of Tor kulkarnii. Inset image: T. kulkarnii holotype (208 mm) from the museum collection of Zoological Survey of India (ZSI), Kolkata

(Fig. 9). Although the species was described by Hamilton (1822), several authors have wrongly attributed the species authority to 'Sykes' (e.g. Khare et al. 2014; Lakra et al. 2010; Mohindra et al. 2007). Described as T. mosal from the Kosi, a river flowing through Tibet and Nepal before entering the Indian State of Bihar, many authors wrongly considered the type locality of T. mosal to be 'Kosi'-another river by the same name which is a tributary of the Ramganga in the northern Indian state of Uttarakhand (for a discussion see Raghavan et al. 2017). Adding to this uncertainty has been the suggestion (see Menon 1992, 1999) that T. mosal is a synonym of the wide ranging golden mahseer, $T$. putitora; although both species can easily be distinguished by their fin ray counts (13 vs. 11 dorsal fin rays, 17 vs. 15 pectoral fin rays; 8 vs. 7 anal fin rays) (see Hamilton 1822) and additional morphological characters mentioned in Hora (1940). In the absence of reliable records backed by voucher specimens, it has become difficult to ascertain the exact distribution range of T. mosal, but it is more or less certain that this species occurs in the rivers of Bihar (and likely further upstream in Nepal) and Assam in India, as well as in northern (Kachin State/Myitkyina) and southern (Tanintharyi/ Dawei) regions of Myanmar (Hamilton 1822; Macdonald 1929; Hora 1940). Although a recent paper (Khare et al. 2014) used genetic data to confirm the species level identity of $T$. mosal using specimens from the tributaries of the Ganges in Uttarakhand and Haryana states, no comparisons were made with topotypic fish from the Kosi River in Bihar, thereby raising doubt over the exact identity of the species and the extension of the distribution range of T. mosal to the middle reaches of the Central and Western Himalayan rivers (Ramganga, Yamuna and Bhagirathi). The lack of reliable distribution records backed by voucher specimens and the non-availability of 


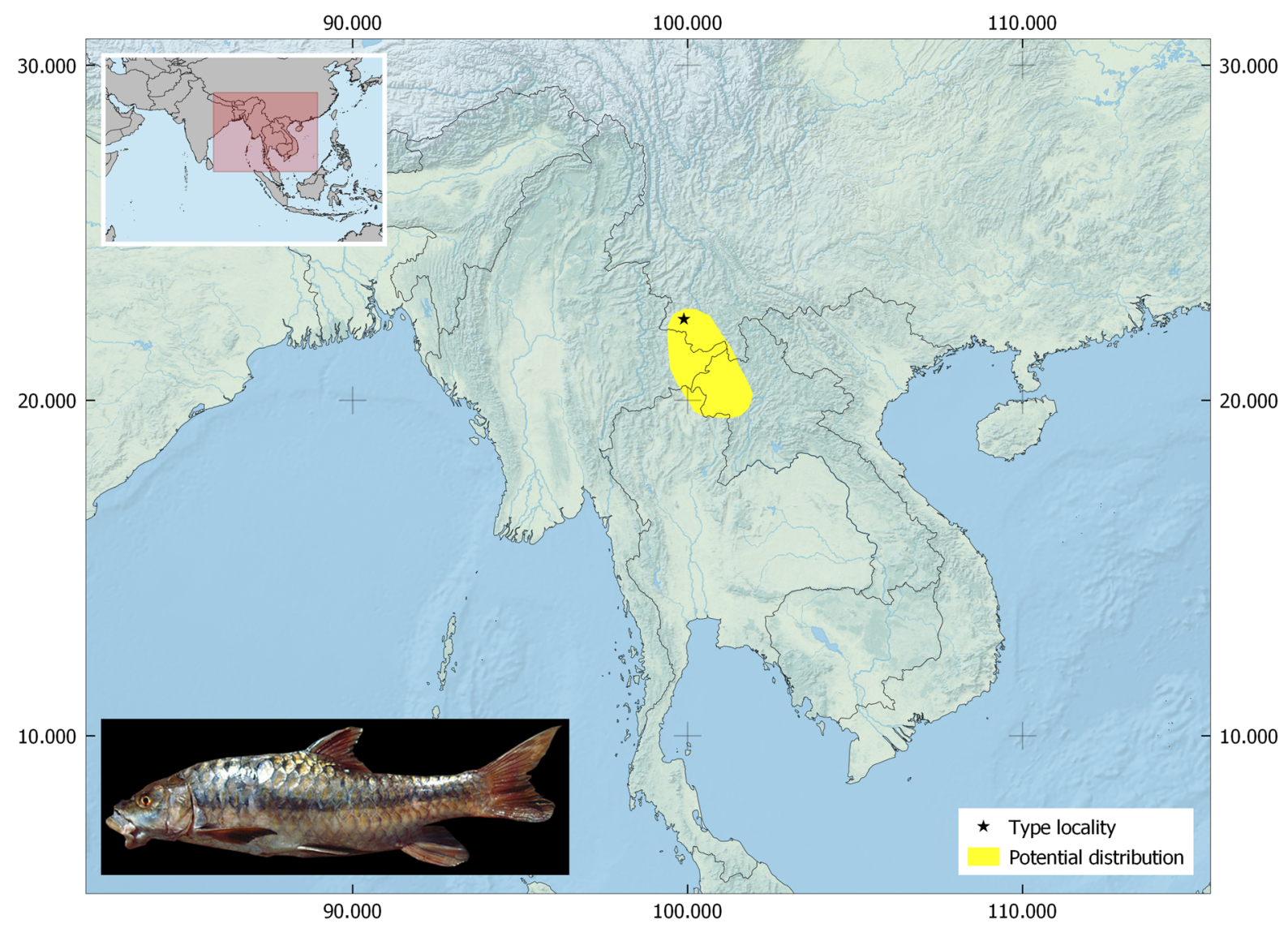

Fig. 7 Distribution of Tor laterivitattus. Inset image: T. laterivitattus collected from a fish market at Louang Prabang, River Mekong basin, Laos. With kind permission Muséum National d'Histoire Naturelle, Paris, France

specimens in the recent past from its type locality has meant that there is very little scientific evidence to carry out a conservation assessment for the species; hence it has been assessed as Data Deficient (Dahanukar et al. 2018b).

\section{Tor polylepis}

Tor polylepis was described from the Nanla tributary of the Lancang Jiang in Yunnan, China (Zhou and Cui 1996) (Fig. 10). It is one of the most poorly known of all mahseers as no information exists on the distribution, ecology, population or threats to the species, leading to a 'Data Deficient' assessment (Huckstorf et al. 2018).

\section{Tor putitora}

Tor putitora was described from Eastern Bengal (now Bangladesh) by Hamilton (1822). This species is naturally distributed throughout the rivers of the South Himalayan drainage (namely the Indus, Ganges and Brahmaputra) from Pakistan (also unverified reports from Afghanistan) in the West, through India, Nepal, Bhutan to Myanmar, with its range also extending throughout the Eastern Brahmaputra catchments encompassing the North-eastern states of India and Bangladesh (Rahman 1989) (Fig. 11). Due to its large size, gaming traits and culinary value, $T$. putitora represents the most comprehensively studied of all Tor spp. (Bhatt and Pandit 2016) and has attracted considerable interest from anglers and amateur natural historians from as early as the $1800 \mathrm{~s}$ (Hamilton 1822). It is the only species of Tor to have been studied for its spatial ecology using 


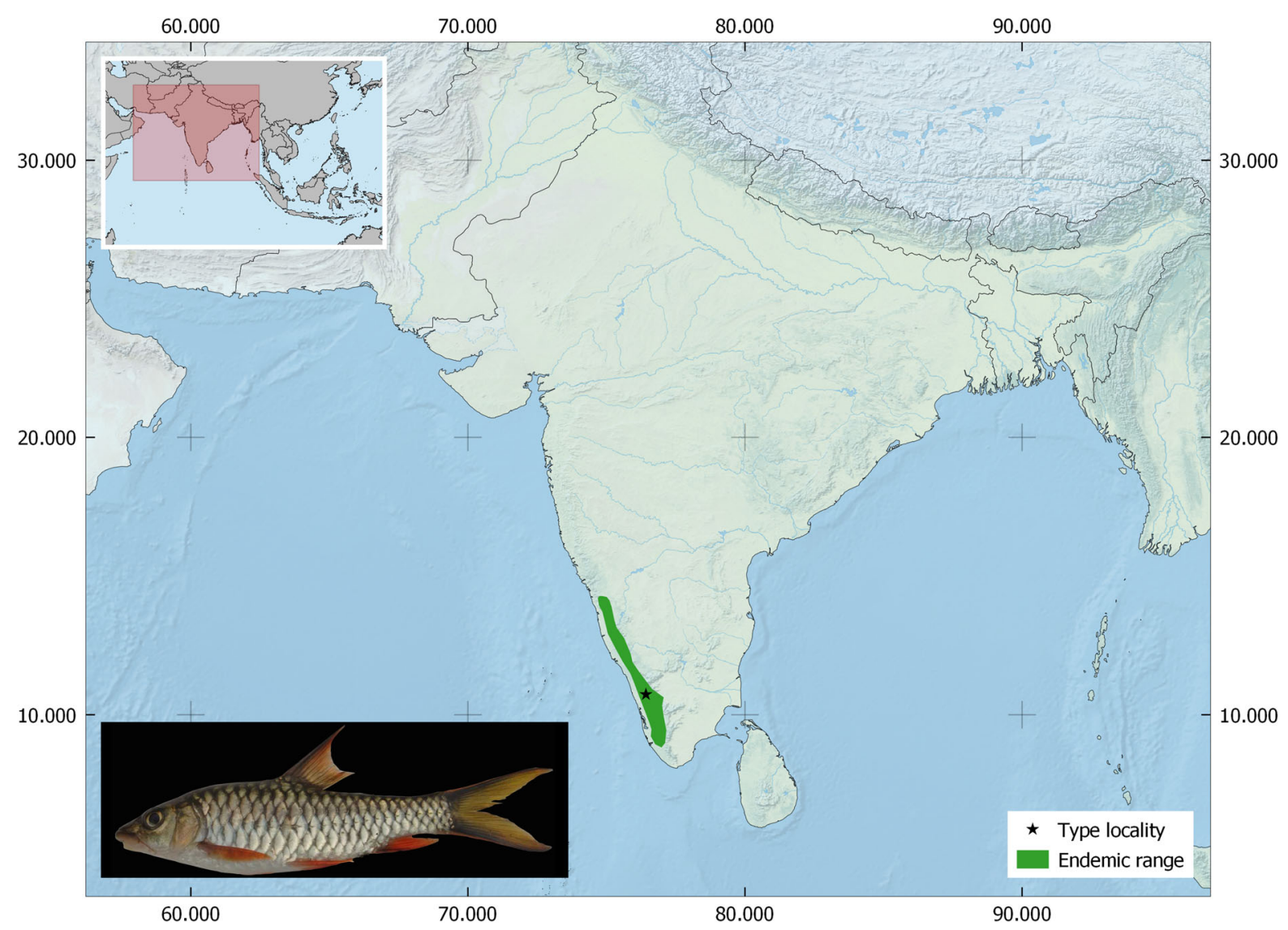

Fig. 8 Distribution of Tor malabaricus. Inset image: T. malabaricus $(260 \mathrm{~mm})$ from the Chaliyar River in Northern Kerala, India

radio telemetry, with recent research in Bhutan revealing large scale migrations ( $>50 \mathrm{~km}$ in a $48 \mathrm{~h}$ period), the utilisation of warmer (non-snow fed) tributaries for spawning, and homing behaviour of individual fish to distinct tributaries on an annual basis (Fisheries Conservation Foundation and World Wildlife Fund-Bhutan pers. comm. 2018).

Despite having been historically reported to attain lengths of $275 \mathrm{~cm}$ (Hamilton 1822) and weights of $54 \mathrm{~kg}$ (Nautiyal et al. 2008), the largest fish reported in the last decade by anglers practicing catch and release have not exceeded $150 \mathrm{~cm}(30 \mathrm{~kg})$ from North India (M. Dhillon, pers. comm.) and $32 \mathrm{~kg}$ from Nepal (I. Martin (pers. comm.). Tor putitora is under severe threat from overfishing, loss and deterioration of key habitats resulting in loss of breeding grounds, and from other anthropogenic effects that have directly resulted in declines in catches in several locations. In addition, the spate of dams constructed and planned in the Himalayan region, is likely to have a cascading effect on the breeding migrations of the species. Population declines inferred from observed cases across the entire distribution range is around $50 \%$ in the past and continuing into the future (if current trends persist). The species is therefore assessed as Endangered and needs urgent conservation efforts to save it from becoming extirpated in several localities (Jha et al. 2018).

\section{Tor remadevii}

Kurup and Radhakrishnan (2007) described Tor remadevii based on 19 juvenile specimens ranging between 114 and $332 \mathrm{~mm}$ from the Pambar, the southern-most tributary of the River Cauvery in Kerala. Probably, based on the paucity of detail included in the original description, a re-description was published in 2010 (Kurup and Radhakrishnan 2010). While this update usefully included a line drawing of the fish, the authors still failed to include 


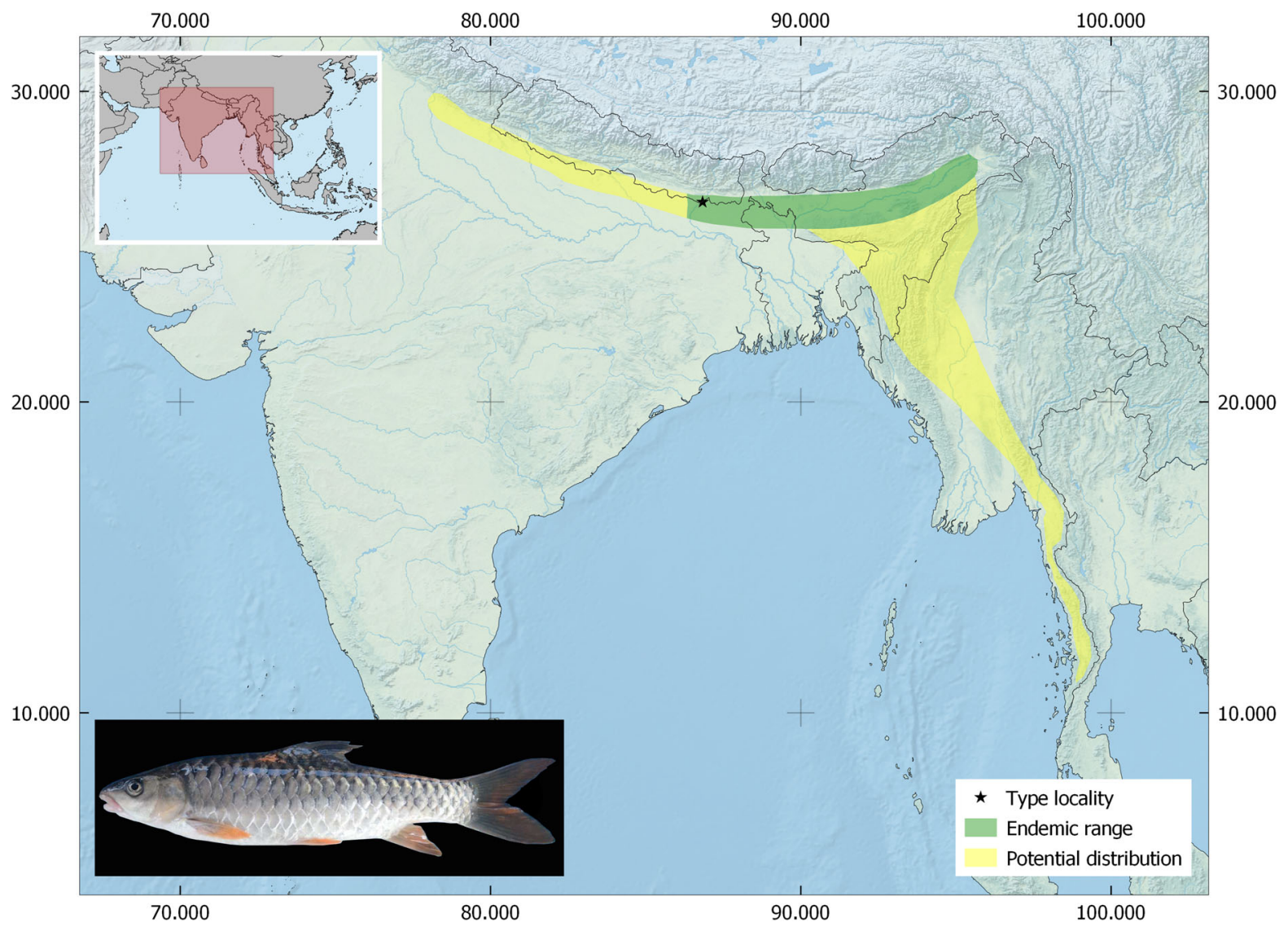

Fig. 9 Distribution of Tor mosal. Inset image: T. mosal from the Brahmaputra Basin. With kind permission B. Amin-Laskar. Note: until collected from the type locality, data are lacking to

photographs, molecular evidence or congeneric morphological comparisons. Despite these descriptive details being limited, recent research has confirmed $T$. remadevii to be conspecific with the iconic humpbacked mahseer of the wider Cauvery catchment (Pinder et al. 2018a), thus affording the hump-backed mahseer the first valid scientific name since it was first brought to the attention of the scientific community in the early nineteenth century (Jerdon 1849).

Endemic and exclusively restricted to the River Cauvery catchment in South India (Pinder et al. 2018a), this species is thought to have been once widespread throughout much of the River Cauvery and its major tributaries (Thomas 1873) (Fig. 12). Following a collapse in recruitment in the main river population during the mid-2000s (see Pinder et al. 2015b), the only spawning populations currently known to persist are restricted to a $40 \mathrm{~km}$ reach of validate the genetic authenticity and physical appearance of $T$. mosal collected from other river systems

the River Moyar, Tamil Nadu (Pinder et al. 2018a) and the Pambar River in Kerala (Kurup and Radhakrishnan 2007). Based on its alarming reduction in population size and persistent threats, T. remadevii is now recognised as the most imperilled of all Tor spp. and the only species to be assessed as Critically Endangered (Pinder et al. 2018b).

\section{Tor sinensis}

Tor sinensis was described from the upper reaches of the Mekong (Lancang Jiang) in Yunnan Province, China (Wu 1977), with its current distribution confined to the upper Mekong River system, from where it has been recorded from Luosuo Jiang, Jinghong and Menghan in Lancang Jiang (Upper Mekong), Yunnan Province, China (Wu 1977; Zhou and Cui 1996); the Nam Theun, Nam Hinboun, Xe 


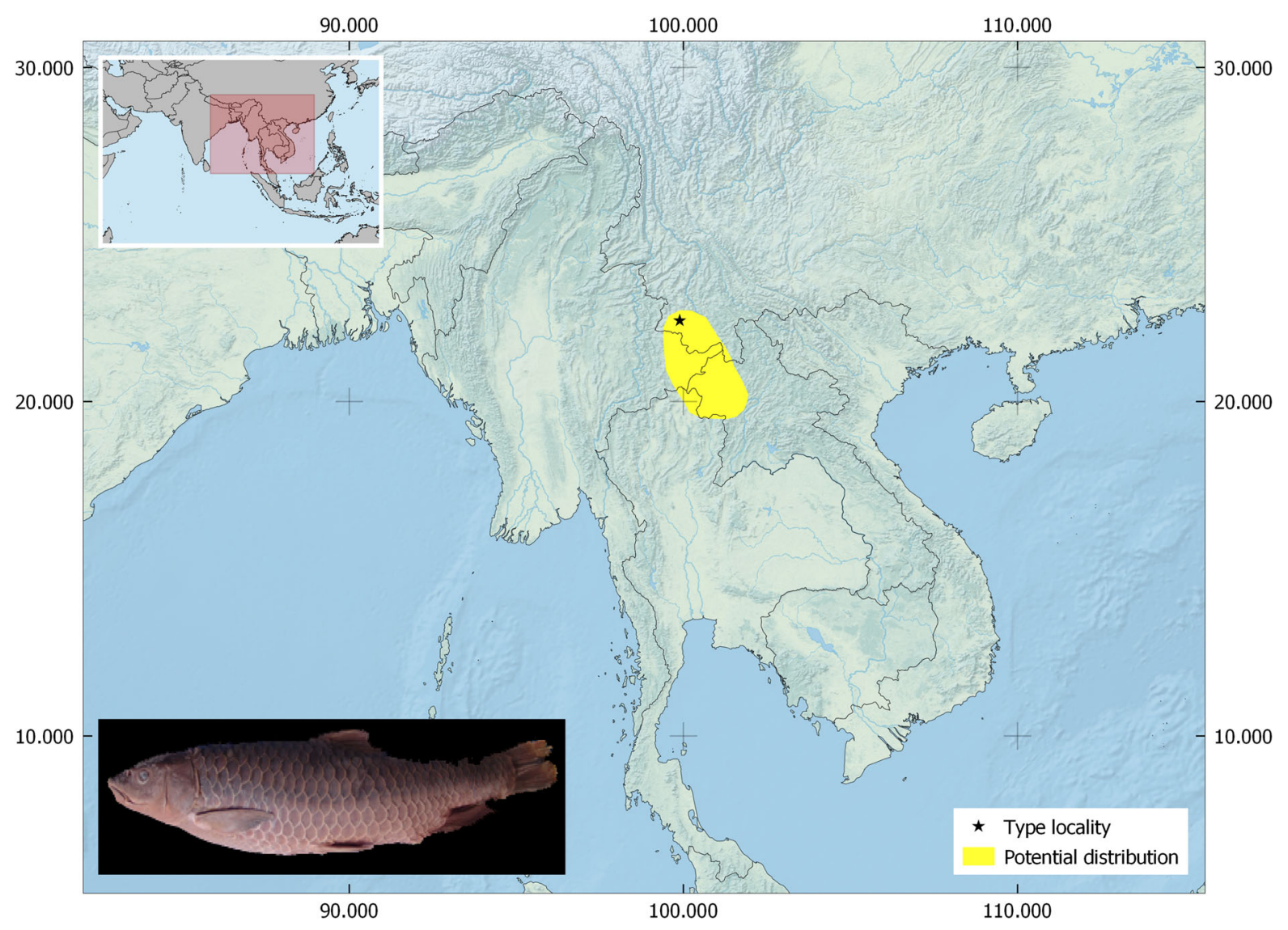

Fig. 10 Distribution of Tor polylepis. Inset image: adult T. polylepis (Holotype KIZ863563) collected from the Lancang Jiang in Yunnan, China and deposited in the Kunming Institute of Zoology, China

Bang Fai, Se Kong and upper Nam Ngum in Lao PDR (Roberts 1999), upper Ea Krong No and Sre Pok River in Vietnam (Hoang et al. 2015) and Nong Khai in Thailand (on the border with Lao PDR) (Kottelat 2000). Despite the apparent wide distribution (Fig. 13), the actual area of occupancy (AOO) of $T$. sinensis is not more than $2000 \mathrm{~km}^{2}$ and the populations exist in nine fragmented basins part of the noninterconnected tributaries of the Mekong System. Due to this restricted distribution and high levels of anthropogenic threats existing and forecasted for the Mekong, most important of which is the megahydropower dams, Tor sinensis is assessed as Vulnerable (Vidthayanon and Pinder 2018).

\section{Tor tambra and Tor tambroides}

Five species names, viz., douronensis, soro, soroides, tambra and tambroides have been commonly referred to in the literature dealing with mahseers of Southeast Asia (e.g. Mohsin and Ambak 1983; Ambak et al. 2012; Ng 2004; Bishop 1973; Kottelat 2013), of which 'soroides' and 'soro' have recently been assigned to the genus Neolissochilus (see Khaironizam et al. 2015). The original descriptions of $T$. tambra, T. tambroides and T. douronensis were based on specimens collected from Indonesia (Cuvier and Valenciennes 1842; Bleeker 1854). The type locality of T. tambroides is Sumatra: Padang, Paja kombo, Solok, Lake Maninjau/Java; and that of T. tambra and T. douronensis is Java: Bogor (see Kottelat 2013) (see Fig. 14). The proliferation of nominal names of Tor from Indonesia is attributed (by Roberts 1993) to the work of Valenciennes (in Cuvier and Valenciennes 1842), who described T. tambra and T. douronensis, and Bleeker (1854, 1863), who recognized all of Valenciennes' Tor species and added one more, $T$. tambroides. These names were subsequently 


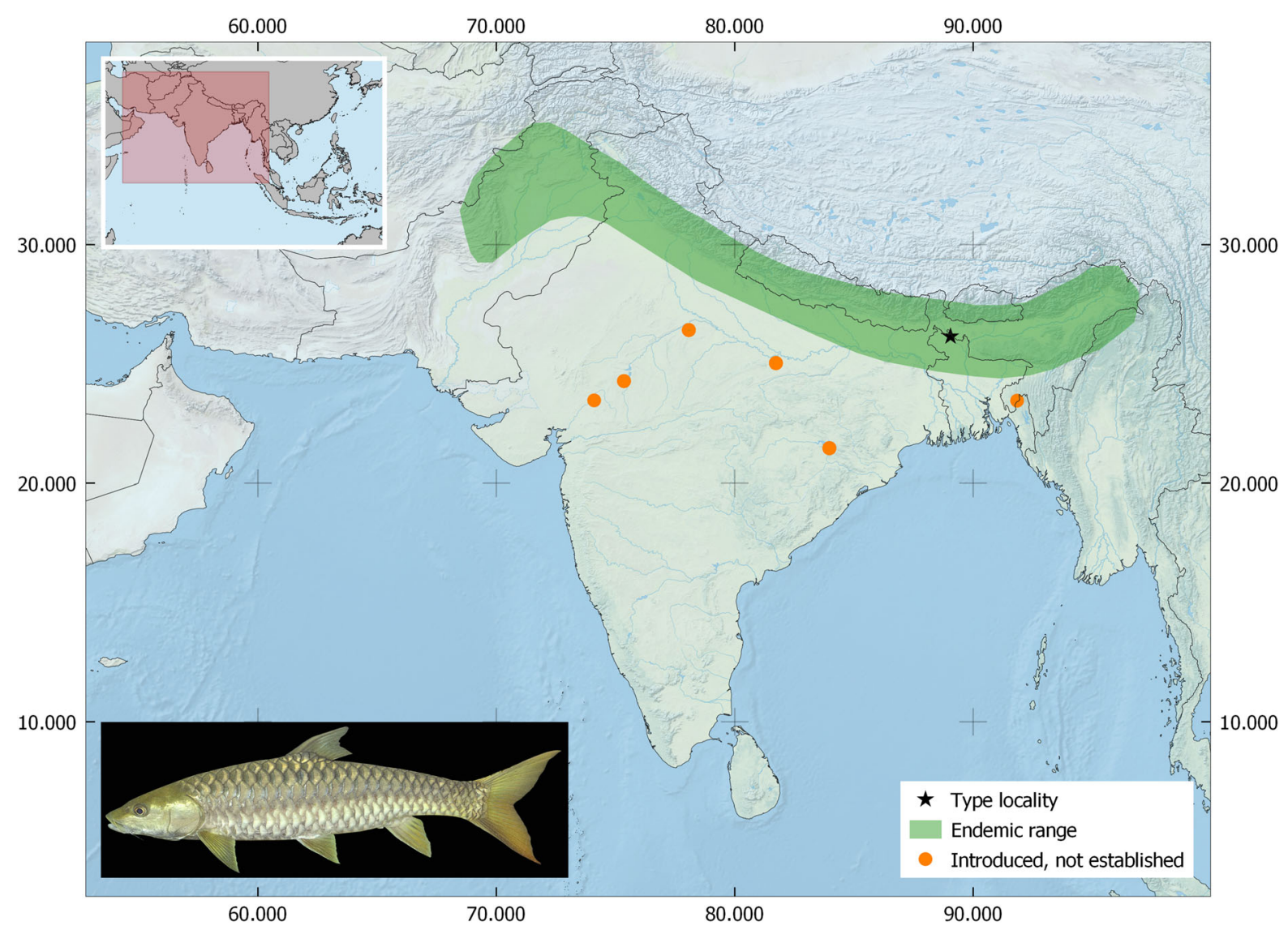

Fig. 11 Distribution of Tor putitora. Inset image: T. putitora photographed by Tristan Tan/Shutterstock.com

recognized (without any detailed studies) and uncritically used in the literature pertaining to freshwater fishes of mainland SE Asia, thus propagating unreliable information over long periods of time. Further, the original descriptions of the three Tor species from Indonesia are vague and ambiguous, increasing the likelihood of misidentification (Walton et al. 2017).

Much confusion still surrounds the taxonomy of these three species. Several authors have suggested synonymy between two or all of these fish. Roberts (1993, 1999) maintains T. tambra (Fig. 14), a species widely reported throughout S.E. Asia, is the senior synonym of several species; T. soro and T. douronensis (now both considered invalid) and $T$. tambroides, but provides little quantitative evidence to support this. Kottelat (2013) considers T. tambroides valid and agrees with the synonymy of $T$. douronensis and T. tambra, based on the similarity of original descriptions of both species, but considered
T. tambroides only to be valid in its type locality (Sumatra and Java), pending comparison of other suggested populations with Javan topotypic material. Topotypic T. tambra has been found to be genetically similar to populations of mahseer occurring throughout mainland S.E. Asia, including populations in Malaysia recorded as T. tambroides (Walton et al. 2017), adding weight to the suggestions of Roberts et al. (1993; 1999), who considered T. tambroides to be a junior synonym of T. tambra. Despite this recent evidence of the misidentification of $T$. tambroides across S.E. Asia (Walton et al. 2017), it cannot currently be concluded that T. tambra and $T$. tambroides are synonymous, as material from Sumatra, identified as T. tambroides, appears to be genetically distinct to all material of T. tambra from the peninsula and Java (Walton et al. 2017). Based on the uncertainties discussed above, both T. tambra and T. tambroides are currently assessed as Data Deficient (Kottelat et al. 2018b, c). 


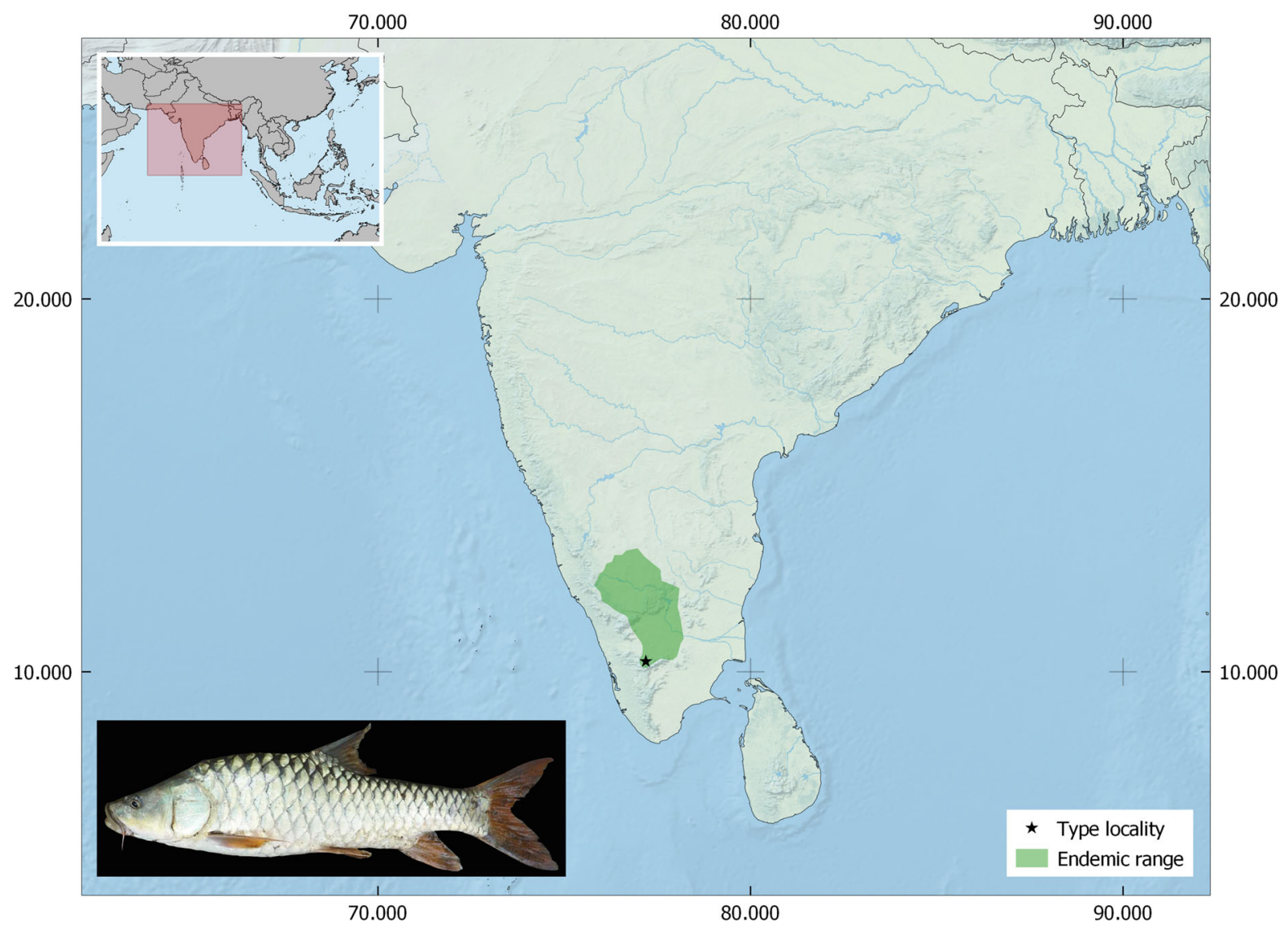

Fig. 12 Distribution of Tor remadevii. Inset image: T. remadevii $(487 \mathrm{~mm})$ from the River Moyar, Tamil Nadu, India

\section{Tor tor}

Frequently referred to as the 'red-fin' or 'deep bodied' mahseer, Tor tor is the type species of the genus. Described by Hamilton (1822) from the Mahananda, a tributary of the Ganges flowing through Northeast Bengal, India, T. tor is considered to be the most widely distributed of mahseer (Lal et al. 2013), with a range extending throughout the South Himalayan drainage from Pakistan in the west to Myanmar in the East, and southwards to the peninsular Indian rivers (Fig. 15). While the westward flowing Narmada River in Madhya Pradesh (Central India) was believed to be the southernmost limit of native distribution (Desai 2003), the recent discovery of T. tor in the Godavari and Krishna River basins (Lal et al. 2013) throws into question whether the species is native to tropical peninsular India, or if range expansion has resulted from the introduction and establishment of populations derived from artificially propagated stock. In spite of a large number of studies on the distribution of $T$. tor in Northern, Central and Southern India, it remains to be proved conclusively whether T. tor of the Mahananda River (type locality) is conspecific with the populations in Central and peninsular Indian rivers from where they have been subsequently recorded. Nonetheless, if the biogeographic range of $T$. tor presented by Lal et al. (2013) is considered accurate, then the apparent wide distribution range of $T$. tor indicates a highly adaptive nature and reveals that the species is naturally eurythermal, inhabiting both cold and warm waters at various altitudes. Previously assessed as 'Near Threatened' in the IUCN Red List due to rapidly declining populations (Rayamajhi et al. 2010), T. tor has been recently reassessed as Data Deficient (Rayamajhi et al. 2018), based on an urgent need to validate the conspecificity of the Mahananda type locality population with records of $T$. tor from other parts of India. 


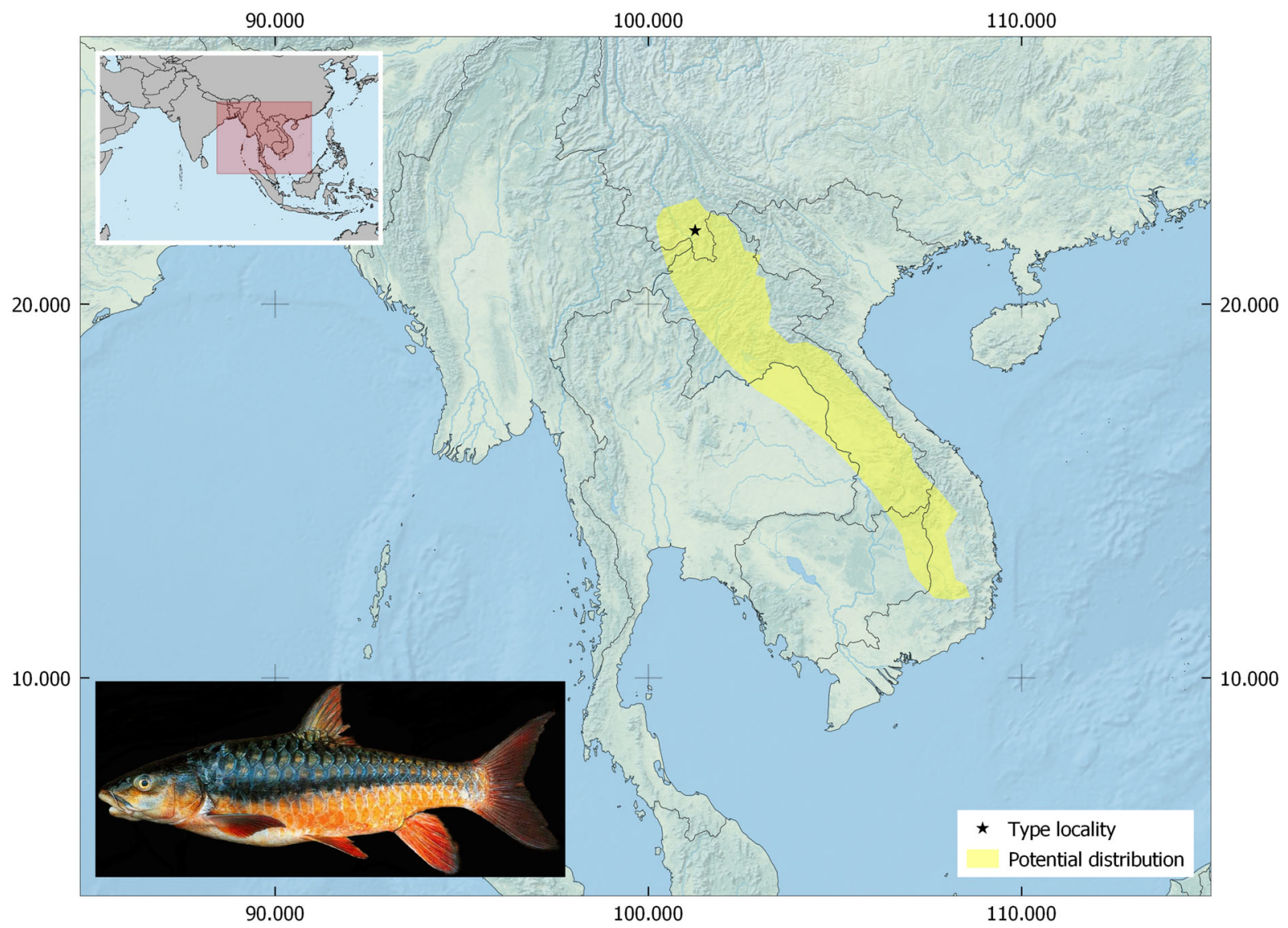

Fig. 13 Distribution of Tor sinensis. Inset image: T. sinensis (465 mm) from the River Mekong, Laos. With kind permission T. Roberts

\section{Tor yingjiangensis}

Tor yingjiangensis, described from the Yingjiang River in the upper reaches of the Irrawady, was long misidentified as $T$. putitora, an allopatric species found in the Himalayan river systems in India and Pakistan (Chen and Yang 2004). The Chinese species is currently known only from the upper Irrawady in the Yunnan province of China, although it could possibly also occur in streams of northern Myanmar as well (Chen and Yang 2004) (Fig. 16). No information exists on any aspect of this species including its biology, ecology and threats and is therefore assessed as Data Deficient (Pinder 2018).

\section{Uncertain species}

At least one species of Tor is present in Sri Lanka, which continues to be referred to as Tor khudree longispinis, considered a sub-species of $T$. khudree (Talwar and Jhingran 1991). Historic angling records, referring to the species as vermin, due to it inhibiting the establishment of introduced brown trout, Salmo trutta (Ceylon Fishing Club 1925), support the endemic status of Tor to Sri Lanka. Exhibiting contrasting pigmentation from the $T$. khudree of South India, this species is commonly known as the yellow mahseer and often displays a dark lateral band of pigment (Fig. 17) which is consistently absent in Indian T. khudree. Recent molecular studies have shown Sri Lankan Tor to be genetically distinct from Indian samples, with an average level of divergence of 0.046 (Nguyen et al. 2008). Accordingly, further taxonomic studies, integrating morphology and molecular techniques are urgently required to elucidate the taxonomic identity and conservation status of this species. Consistent with other Tor, this species is likely to be of high conservation concern as 


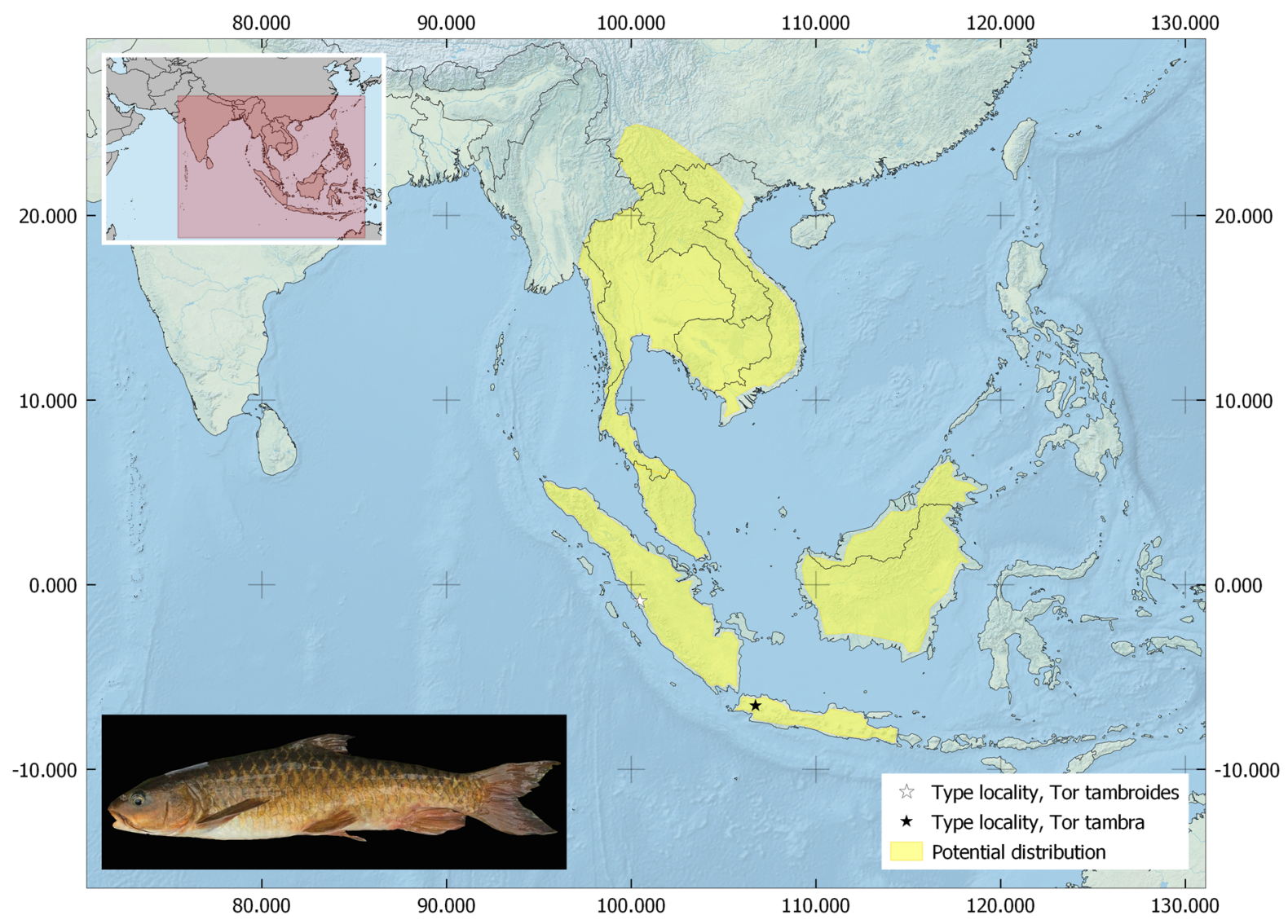

Fig. 14 Distribution of Tor tambra and Tor tambroides. Inset image: T. tambra (560 mm) from the Serayu River basin South-central Java, Indonesia

evidenced by reports in the mid-1900s of the species becoming scarce, with individual fish rarely reaching the once common weights of over $10 \mathrm{~kg}$ (Department of Fisheries, Ceylon 1958).

Despite considerable recent progress in resolving taxonomy across the genus Tor, fundamental knowledge gaps continue to persist across Asia. Once filled, these may result in further major taxonomic revisions. Such revisions may be due to the addition of new previously undescribed species from poorly researched regions, or through molecular and morphometric evidence from type localities, concluding erroneous former con-specificity assumptions.

\section{Mahseer conservation}

The recent Red listing of the 16 species in the Tor genus (Table 1) should provide fresh impetus to their conservation efforts and guide prioritised research to address remaining data deficiencies. Although it has been outlined that a series of substantial anthropogenic threats remain and continue to imperil populations, there are also various opportunities to conserve Tor spp. throughout its native range. These opportunities are outlined in the following subsections.

\section{Recreational fishing}

Recreational fishing, where fish are captured using a variety of gears for purposes other than consumption (fish do not constitute the fisher's main source of protein) or sale (fish are not sold or traded at market), is a highly popular activity occurring worldwide (FAO 2012), particularly in inland waters (Cooke et al. 2016a). In highly industrialized countries, recreational fisheries are the largest fishing sector in 


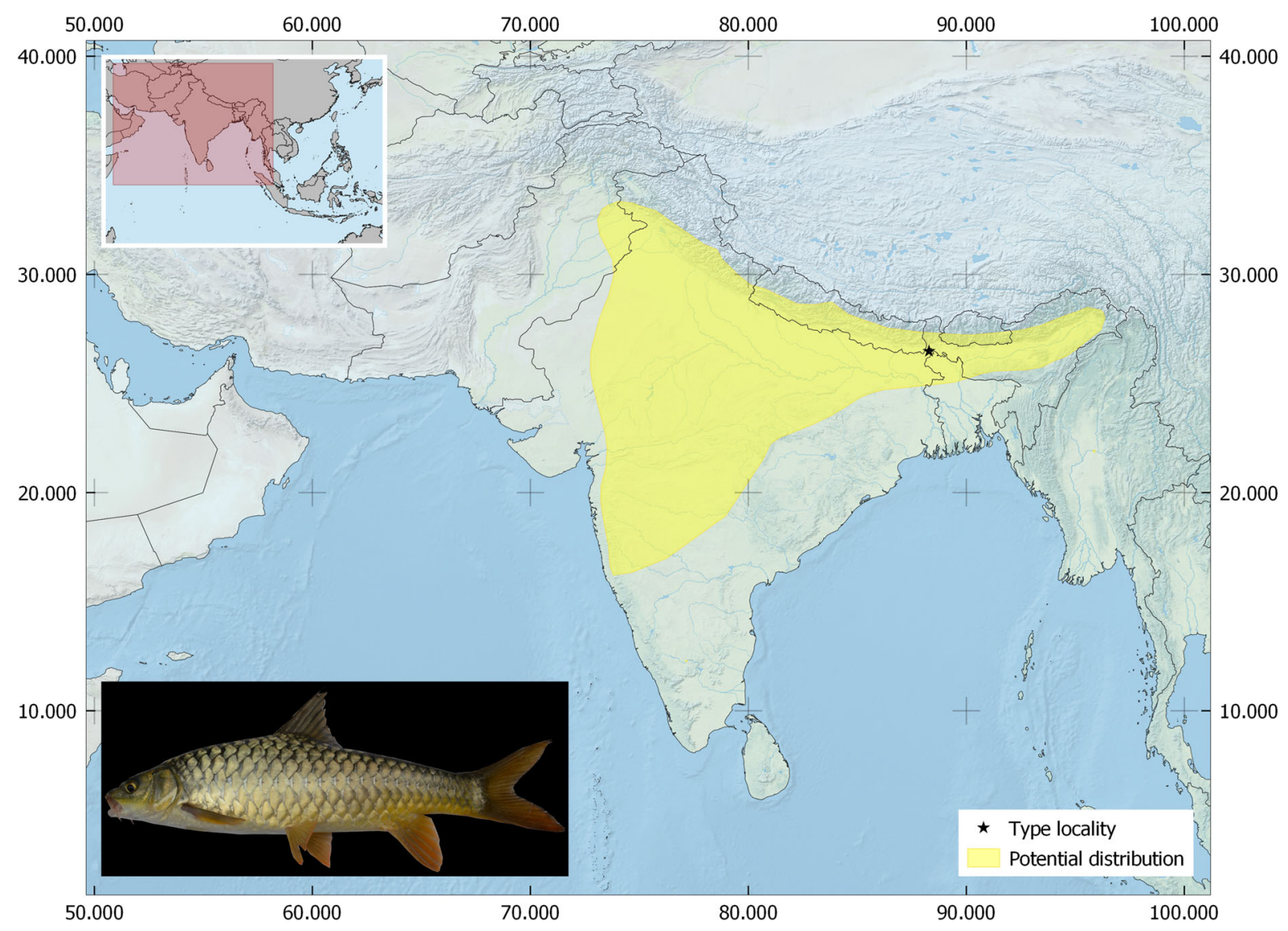

Fig. 15 Distribution of Tor tor. Inset image: T. tor (410 mm) from the Choral River in the Narmada River basin, Madhya Pradesh, India. Note: until collected from the type locality, data

inland waters (in terms of both revenue generated and catches reported; Arlinghaus et al. 2015). Estimates suggest that in highly industrialised and transitioning countries, over $10 \%$ of people engage in recreational fishing activities (Arlinghaus et al. 2015), and recreational fishing is believed to be growing rapidly in less industrialised countries around the world (Bower et al. 2014). Several important benefits of recreational fishing activity have been identified ( $c f$. Arlinghaus and Cooke 2009). For example, conservative estimates of global recreational fisheries expenditures indicate that recreational fisheries generate $\$ 190$ billion USD in direct expenditures annually (World Bank 2012). In addition, numerous psycho-social benefits have been ascribed to recreational fishing activities, including heightened relaxation and improved relationships with nature (Fedler and Ditton 1994; Fedler 2000). In fishing are lacking to validate the genetic authenticity and physical appearance of $T$. tor collected from other river systems

communities of the developing world, recreational fisheries can play a different role. Small-scale fishing activity provides the main source of income and protein for millions of people around the world, and these same communities are less resilient to ecological and economic shocks (FAO 2010). Recreational fisheries can act as a livelihood buffer in these communities, providing an important source of income through additional or alternate forms of livelihood (Barnett et al. 2016).

To evaluate recreational fisheries as a conservation tool, the negative impacts and potential trade-offs of the activity need consideration. Recreational fishers (anglers) utilise approaches ranging from entirely catch-and-release (C\&R; returning captured fish to the water, presumably unharmed; Arlinghaus et al. 2007) to entirely catch-and-harvest (Cooke et al. 2018). In harvest-based recreational fisheries, the 


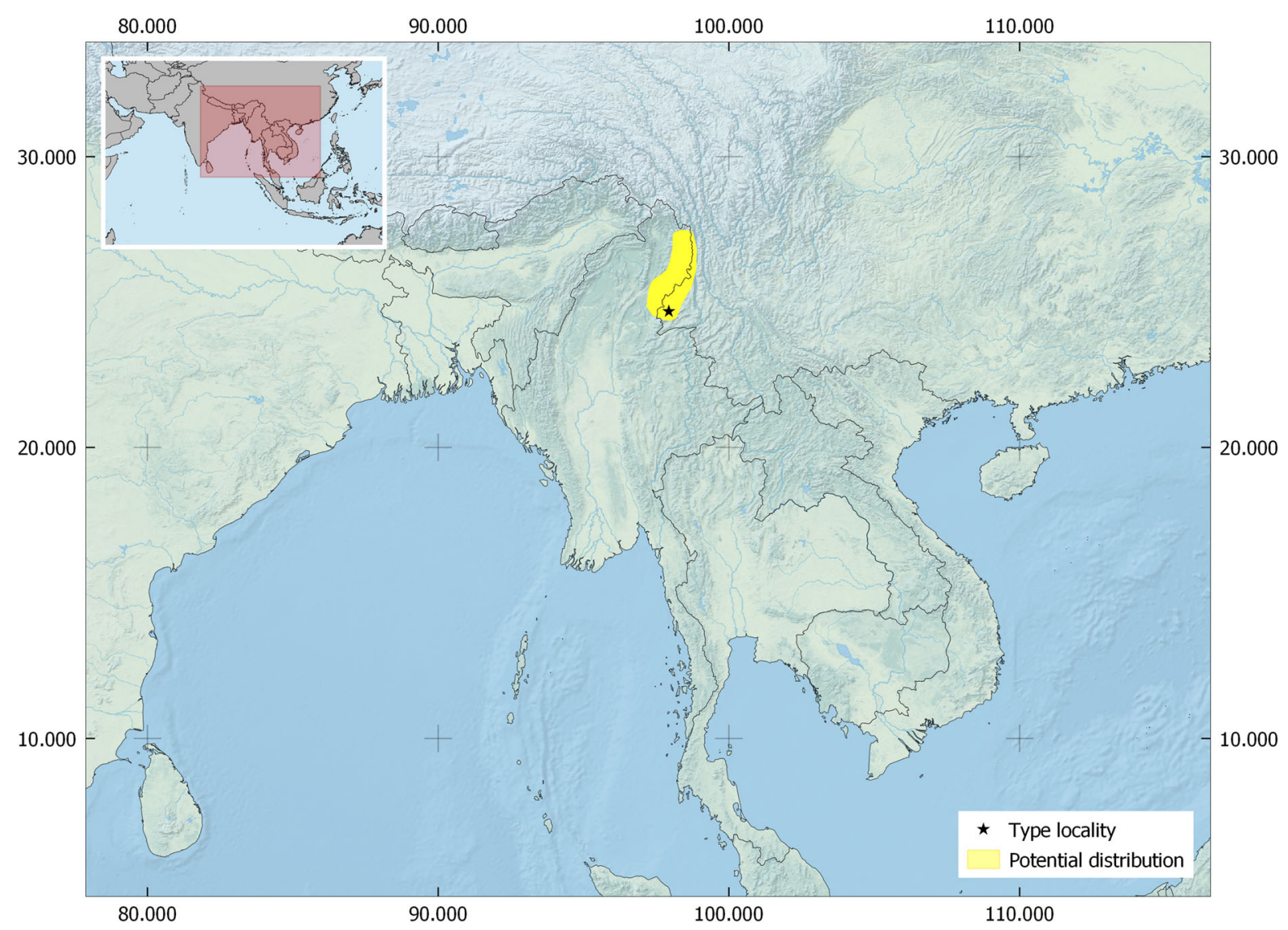

Fig. 16 Distribution of Tor yingjiangensis

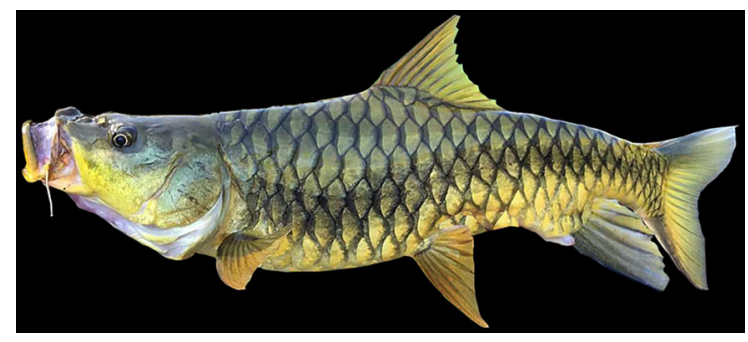

Fig. 17 The yellow mahseer of Sri Lanka currently recorded in literature as Tor khudree longispinnis

amount of harvest must be accounted for in management models to ensure sustainable management (Lester et al. 2014). In C\&R fisheries, or fisheries that permit or require (e.g. due to harvest regulations) a combination of behaviours, managers must account for additional sources of mortality (immediate mortality, Muoneke and Childress 1994; post-release mortality, Bartholomew and Bohnsack 2005), with angling-induced mortality rates varying widely between species (Cooke and Suski 2005). Recreational fishing is, however, rarely considered a factor in the endangerment of fishes, although it has been a factor in the localized extinctions of some populations (Post et al. 2002; Post 2013; Johnston et al. 2014) and has resulted in phenotypic and behavioural changes in others (Jorgensen et al. 2007; Arlinghaus et al. 2010; Alós et al. 2012). Furthermore, numerous data deficiencies are high (e.g. only $39 \%$ of known fish species have been assessed by IUCN to date; IUCN 2018), constraining the evaluation of conservation actions.

The role of recreational fishing in fish conservation includes promoting conservation through participation in research and citizen science (Granek et al. 2008). This highlights the relationship between recreational fishing and animal welfare (Arlinghaus et al. 2012) using recreational angling to protect threatened and endangered species (Cooke et al. 2016b), with species-specific examples including 
Hucho taimen (Jensen et al. 2009), Lutjanus goldiei (Sheaves et al. 2016) and T. putitora (Everard and Kataria 2011). Thus, recreational fisheries can play positive roles in conservation (Tufts et al. 2015). However, there are currently few case studies that describe recreational fisheries as a positive factor in fish conservation in the longer-term. This is partly due to the often ignored and highly complex social and cultural attributes of recreational fishing, including understanding angler motivations and behaviours, relationships among governance entities, and community perspectives (for e.g. Hunt et al. 2013; Naiman 2013; Stensland and Aas 2014). Increasingly, researchers are recognising the importance of socialecological relationships in recreational fisheries and the need to account for interactions among these systems in their evaluation (Barnett et al. 2016; Arlinghaus et al. 2016, 2017). This viewpoint is particularly relevant when examining recreational fisheries targeting mahseers, where differing cultural, traditional, and social norms can produce different conservation outcomes, depending on the existing and potential degree of support for recreational fishing as an activity, and for conservation more broadly.

Recognised as a sporting challenge to anglers as early as the twelfth century ( $c f$. 'Role in history, religion and culture), mahseers were credited for their fighting qualities in 1833 in the Oriental Sporting Magazine (Cordington 1946), before being further popularised across India during British occupancy (Thomas 1873; Dhu 1923; MacDonald 1948). Following Indian independence in 1947, interest in mahseer fishing diminished, leaving the few who knew of the fish to believe they had become extinct. However, in 1978, a small team of British explorers were successful in catching mahseer to $42 \mathrm{~kg}$ (TWFT 1984), which reignited a global interest in mahseer angling and conservation, and launched a new era of Indian angling ecotourism (Everard and Kataria 2011; Pinder and Raghavan 2013).

Case studies of how recreational fisheries have supported mahseer conservation in India can help guide future fisheries management policy across Asia. In Uttarakhand, the potential of 'payments of ecosystem services' (PES) markets based on recirculation of revenues from recreational anglers to local people has been recognised as a potentially powerful conservation mechanism. Based on the longer-term revenues from $C \& R$ fisheries exceeding the immediate-term market value of harvested fish, this has led to the incentivised community policing of illegal and destructive fishing (Everard and Kataria 2011). Pinder and Raghavan (2013) described the role of recreational fisheries on the Cauvery River in Karnataka as positive overall, with local NGOs sustainably managing fisheries and offering alternative employment as guides and guards to fishers that previously used illegal tactics to catch fish. Angler catch data has been applied to track changes in mahseer size and weight (Pinder et al. 2015a). Bower et al. (2017) used a participatory approach to include stakeholders in priority-setting activities, finding that a social-ecological systems approach was warranted in studying mahseer recreational fisheries in both Karnataka and Uttarakhand. When examining angler perspectives, Gupta et al. (2015) found that most anglers are aware of the conservation status of mahseer and indicated high willingness to contribute time and money to supporting conservation. A subsequent study found that blue-finned mahseer ( $T$. khudree) in the Cauvery River are physiologically resilient to the process of $C \& R$ but suggested that best practices should include minimizing angling time and air exposure to reduce post-release mortality (Bower et al. 2016).

While there is an emerging trend amongst major wildlife organisations, conservationists and scientists towards encouraging angling tourism to support the conservation of mahseer and other sport fishes throughout their ranges, recent scrutiny and reinterpretation of the Indian Wildlife (Protection) Act 1972 (WPA) led to a national prohibition of angling within protected areas, thus terminating the incentivised stock protection practiced over a preceding period of four decades on the River Cauvery (Pinder and Raghavan 2013; Pinder et al. 2015a; 2015b). As a consequence, opportunities for angling on the River Cauvery are currently limited. Despite growing participation levels in recreational angling throughout mahseer range countries, interest in mahseer fishing is now largely focused on the catch and release of $T$. putitora from the Himalayan drainage, with some interest in the wild rivers supporting T. tambra in Thailand also evident. While there remains much scope for the development of mahseer angling tourism, organised recreational angling opportunities are currently limited. 
Aquaculture

Mahseer conservation has tended to rely heavily on the production of hatchery-reared mahseers for release into the wild as a mitigation measure of, for example, loss of river connectivity due to hydropower development. Captive breeding mahseer for conservation and stock enhancement was first carried out in India by the Tata Electric Company (TEC) at Lonavla in Maharashtra in the 1970 s, and gradually expanded to Nepal, Bangladesh and Malaysia. Millions of seeds of various mahseer species (T. khudree, T. putitora and an ambiguous species 'Tor mussullah') have been bred at Lonavla and distributed to various State Fisheries Departments and other stakeholders throughout India (and elsewhere), primarily for stock enhancement in natural waters (Ogale 2002).

Currently, techniques for breeding and artificial propagation are available for many of the popular mahseer species including T. khudree, T. putitora, T. tor and T. tambroides (Gurung et al. 2002; Ogale 2002; Ingram et al. 2005, 2007). Early hatchery production of mahseer juveniles were derived by hand stripping wild-caught mature spawners during the breeding season, with or without artificial hypophysation (Ogale 1997), but has now expanded to the use of pond-reared broodstock (Gurung et al. 2002; Ingram et al. 2005; Joshi et al. 2002). Advances in the standardisation of effective induced breeding and seed production technology has enabled development of grow-out techniques that cut across the boundaries of traditional pond-based farming systems to highly sophisticated cage farming (Kohli et al. 2002; Shahi et al. 2014; Sarma et al. 2016).

Evidenced by photographs available from TEC hatchery in Lonavla, Maharshtra (A. Pinder pers. obs.), Tor remadevii, the hump-backed mahseer (under the guise of 'T. mussullah') is known to have been translocated to Lonavla from the River Cauvery for aquaculture trials in the $1970 \mathrm{~s}$ and successfully hybridised with T. putitora (Ogale 2002). No further records are available to determine the level of breeding success of ' $T$. mussullah' at Lonavla and efforts appear to have been redirected in favour of the culture of T. khudree, (Kulkarni 1971; Kulkarni and Ogale 1978), T. tor (Ogale and Kulkarni 1987; Ogale 2002) and T. putitora (Tripathi 1978; Pathani and Das 1979).
The Indian Council for Agricultural ResearchDirectorate of Coldwater Fisheries Research (ICARDCFR) is involved in breeding of T. putitora; the fingerlings of which are used for rehabilitating both rivers and lakes in North Eastern India (Sarma et al. 2016). Currently, five mahseer hatcheries operate in India, producing fry and fingerlings primarily for the purpose of ranching and stock enhancement to aid conservation. There is very little information on whether the breeding and culture trials for mahseer in Nepal and Bangladesh (see Shrestha 2002; Gurung et al. 2002; Rahman et al. 2005) have resulted in commercialisation for either food or conservation aquaculture, or even stock enhancement and ranching. Similarly, although the captive breeding techniques for the sundaic species, T. tambra and $T$. tambrodies have been standardised (Ingram et al. $2005,2007)$, there is a paucity of information to demonstrate its effectiveness for conservation, despite some commercial-scale farming operations being in existence. Since the inception of Tor aquaculture, there are numerous examples of seeds of individual species being distributed beyond their natural geographic range (see Ogale 2002). While such activities directly negate conservation action and will have resulted in unknown impacts on local biodiversity, recent raised awareness (e.g. Pinder et al. 2015b) has resulted in some Indian aquaculture facilities recognising the importance of endemic biodiversity and has subsequently driven a shift towards preserving indigenous Tor spp. by limiting culture to only using locally sourced broodstock. Overall, despite considerable effort over the last 50 years to utilise aquaculture as a tool to assist the conservation of wild mahseer, there remains a comprehensive lack of population monitoring, both pre- and post-stocking, to quantify the efficacy of these efforts.

\section{Restoration of river connectivity}

As already highlighted ( $c f$. Population Threats), instream engineering projects represent a major and escalating anthropogenic threat constraining mahseer populations across their entire biogeographic range. While mega-hydroelectric dams are known to exclude the upstream migration of all fishes, the bio-permeability and impact of smaller structures (e. g. check-dams designed for storage and irrigation) 
also have the potential to fragment the accessibility of key functional habitats by disrupting or obstructing the access of adult cyprinid fishes to their spawning grounds (Ovidio and Philippart 2002). Although large-scale habitat restoration for mahseer is currently constrained due to a paucity of knowledge on their ecological requirements across different lifestages ( $c f$. Future Research Opportunities), incorporating fish passes into the design of future projects and the retrofitting of easements on existing barriers has the potential to deliver relatively rapid benefits via enabling the movement of mature adults to access upstream spawning areas. The construction of fish passes on migration barriers has been a common practice in the last 50 years (Wilkes et al. 2018) and although engineering solution designs have been traditionally heavily skewed towards salmonid fishes (Birnie-Gauvin et al. 2018), there are a growing number of studies which have demonstrated appropriate designs which incorporate species specific biological knowledge of behaviour and swimming performance (Williams et al. 2012), can be at least partially successful for enabling the upstream passage of potamodromous cyprinids (Santos et al. 2012; Romão et al. 2017). Notwithstanding the need for appropriate design, the conservation benefits of reconnecting migratory pathways for mahseers would also critically depend on the ability of juveniles to safely navigate these structures during their downstream migration (Kemp and O'hanley 2010).

Freshwater protected areas

The true extent of the world's fresh waters covered by the protected area (PA) network remains largely unknown (Saunders et al. 2002). Although, 15.4\% of the world's 'terrestrial and inland waters' (combined) are under the PA network (Juffe-Bignoli et al. 2014), the 'inland/freshwater ecosystems' within terrestrial PAs receive only incidental protection (Saunders et al. 2002). Estimates of the area within mahseer distribution range that fall inside the terrestrial PA network is also not known for many species, but for some range-restricted species such as $T$. remadevii, terrestrial PAs play a significant conservation role as they encompass $\sim 70 \%$ of the current species distribution range. Since the majority of national PA networks are biased to higher elevations, steeper slopes and greater distances to urban settlements
(Joppa and Pfaff 2009), they coincide with the ecological requirements and distribution of mahseer (i.e. middle to upper reaches of major rivers), and thus have high potential for playing a major role in their current and future conservation.

Even in cases where mahseer populations occur inside PAs, their effectiveness is not typically encouraging. Illegal fishing often using unsustainable gears, alien invasive species, and a combination of other anthropogenic threats (e.g. river fragmentation, abstraction, pollution) is known from both inside, as well as areas upstream and downstream regions of many Indian PAs (Gupta et al. 2014; Raghavan et al. 2011). In reservoirs and streams inside terrestrial PAs, where mahseer can be legally exploited (largely through the provision of the Indian Forest Rights Act), fishing mortality and exploitation rates have been observed to be above the optimal limits, indicating the need for urgent management interventions (Raghavan et al. 2011). The only current example of a PA designated exclusively for the protection of mahseer is the Poonch River National Mahseer Park, Pakistan, that flows through Azad Jammu Kashmir (AJK). Initiated as a joint venture between the AJK government and the Mira Power Company Ltd, $62 \mathrm{~km}$ of the river has since been afforded protection from illegal exploitation, with the support of newly enacted legislation (AJK Wildlife and Fisheries Act 2010), deterring poachers and allowing the population of $T$. putitora to persist. Alongside the legal protection, a system of rural support ensures $80 \%$ of the revenue generated inside the PA goes to local villagers (A. Rahman pers. comm.).

However, in Rajasthan state, India, proposals for statutory designation of a mahseer reserve are in hand for Lake Badi (Badi Ka Taalab). Rajasthan High Court (2017), responding to Civil Writ Petition No. $7077 / 2014$, ruled on a motion to protect and conserve mahseer fishes in the waters of Badi Lake $(24.6161050 \mathrm{~N}, \quad 73.6221270 \mathrm{E}$, surface area $155 \mathrm{~km}^{2}$ ), formed by a dam on the Morvaniya river upstream of Udaipur installed by Maharana Raj Singh I (1652-1680). The ruling of the Rajasthan High Court concurred that pollution and development in Udaipur had eradicated mahseer from lakes surrounding the city, but that Lake Badi should be protected to conserve these fishes by the banning of motorised boats, stoppage of pollution from seven sources and a 
ban on encroachment by slums (kachi basti). The Forest Department (2018) consequently developed a document Mahseer Conservation Reserve, Badi Lake, Udaipur, submitted to Government of Rajasthan to support statutory designation of the reserve in large measure in recognition of its value as a mahseer reserve, also recognising the importance of the lake for migratory and resident aquatic birds, other fish fauna (Katla, Rohu, Mrigal, Sarsi and Bam are cited), water snakes, frogs and other wildlife, as well as a water resources for irrigation (-of rabi (dry weather) crops and for drinking. (Two mahseer species-T. tor and T. khudree-are cited, though the taxonomy of Lake Badi's mahseer is currently under investigation.) The reserve is proposed to encompass the upstream Kaler Reserve Forest as well as the lake, noting that "Hence an unaltered, natural and original ecosystem is needed to save the ichthyofauna and other water life of Badi lake". First amongst the twelve objectives proposed for the Lake Badi Mahseer Conservation Reserve is conservation of mahseer fishes "Mahseer" (following the direction of Rajasthan High Court) as well as other aquatic and terrestrial biodiversity, water quality, and to promote ecotourism including catch-and-release angling with the active support of local communities. In addition to pollution control and habitat enhancement measures, the proposal includes removal of upstream obstacles to fish migration, protection of breeding fish through a closed season (under section 5 of Rajasthan Fisheries Act 1953 and fisheries rules 1958) as well as a ban on measures such as sand mining and related damaging activities under the oversight of a monitoring committee and a Conservation Reserve Management committee.

Informal forms of protected areas also exist throughout India, where mahseer are revered as god's fishes (Gupta et al. 2015). Religious sentiments have helped protect the endangered golden mahseer ( $T$. putitora) in several tributaries of the River Ganges, while peninsular Indian species of Tor (T. malabaricus and T. khudree) continue to be protected in several stretches of rivers associated with temples (Dandekar 2011b), where exploitation is prohibited and local communities, pilgrims and temple authorities help monitor and safeguard the fish population (Gupta et al. 2015). Yet another protection strategy for mahseer has been through community-managed areas, the classical example of which is the 'Tagal' system of Borneo which was initiated by the communities in response to dwindling fish resources in the early twentieth century (Wong et al. 2009). Under the Tagal management system each pre-assigned stretch of a river is divided into three zones: red, yellow and green, each differing in access and regulations on fishing. Currently 240 Tagal systems are in operation in Sabah helping protect the Malaysian mahseers.

Integration with wider environmental protection policy

Recognition of both the taxonomic validity and conservation status of mahseer fishes also offers the potential to integrate them into wider conservation mechanisms beyond the IUCN Red List. These large omnivorous fishes can act as top predators, potentially acting as key agents in trophic cascades, but also as 'flagship' and 'umbrella' focal species; thus mobilising wider public support for protection and restoration of the networks of interconnected habitats upon which they depend to complete their life cycles (Caro 2010), along with associated uplift in other species and linked ecosystem services beneficial to human communities (Everard et al. 2011). Populations of mahseer fishes, then, can have a direct role as key indicators of the "wise use" of wetlands (Ramsar Convention Secretariat 2010), wherein exploitation is balanced with protection of the ecological character of the river systems they inhabit.

Mahseer and their sustainable use can also benefit from protections such as management of their host ecosystems under the principles of the Convention on Biological Diversity (https://www.cbd.int [accessed 12/03/2019]); with particular emphasis placed on following the Ecosystem Approach and ensuring exploitation is governed by the Nagoya Protocol (on Access and Benefit Sharing). Controls on the spread ing of invasive hybrid species arguably also fall under the aegis of the Cartagena Protocol on Biosafety to the Convention on Biological Diversity. Additional conservation tools, such as the Conservation Manage ment System (https://www.software4conservation. com [accessed 12/03/2019]), can also be applied within an adaptive management framework to secure the long-term viability of mahseer (and other linked species) populations and the habitats upon which they depend. 


\section{Future research opportunities}

In synthesising the current state of knowledge pertaining to Tor spp., this review has highlighted a series of high uncertainties regarding species taxonomy, distributions, population status and ecology that provide substantial research opportunities outlined in this subsection.

\section{Species taxonomy}

There have been some recent advances in taxonomic knowledge in the Tor genus that have removed some of the ambiguities that have been problematic for conservation (Pinder et al. 2018a). Original descriptions of some Tor fishes do, however, contain inconsistencies and ambiguities, with an absence of accompanying voucher specimens, increasing the likelihood of potential misidentifications (Walton et al. 2017). Consequently, there remains an outstanding research requirement for a comprehensive mahseer range-wide taxonomic study across all major drainage basins, incorporating molecular taxonomic studies using multiple mitochondrial and nuclear genes, and accounting for all visible diagnostic characteristics to discriminate between species.

Species distributions and population status

Coupled with their taxonomic ambiguities, there remains a paucity of information on the distribution ranges of some Tor fishes. This is at least in part due to resourcing issues around field expeditions, given the range of many mahseer fishes are in developing countries where funding for biodiversity assessments tend to be limited. It might also relate to issues around many mahseer species being present in rivers that are relatively remote and/or difficult to sample. This flags the importance of frequent reviewing and revising Tor IUCN Red List assessments in accordance with emerging evidence.

A method that potentially helps overcome this issue is the widespread application of environmental DNA (eDNA), a method based on detecting species DNA from water samples (Jerde et al. 2011; Davison et al. 2016; Turner et al. 2015). The method is increasingly being applied to the monitoring of freshwater species, including those of conservation importance (e.g. Takahara et al. 2012; Thomsen et al.
2012). eDNA can be used to screen to characterise whole communities of organisms using 'metabarcoding' (Lawson Handley 2015; Hänfling et al. 2016). For determining mahseer distributions, however, a more cost-effective method could be used of specific primers in real-time PCR that enable detection of the presence/absence of a specific Tor species. Although representing a major development in mapping species' distributions, a number of issues remain on its use, given multiple factors influencing DNA dynamics in the environment (Barnes et al. 2014). For example, the non-detection of species-specific DNA fragments in a sample of river water does not automatically imply the absence of the target species (Lacoursiere-Roussel et al. 2016).

\section{Ecological knowledge gaps}

Over the last 20 years, the attention researchers have applied to ecological aspects of study across the genus has been negligible ( $c f$. Figure 1) and entirely limited in focus to just two species, T. putitora (Shrestha 1997; Nautiyal et al. 2001; Nautiyal 2014; Bhatt and Pandit 2016) and T. tor (Shrestha 1997; Desai 2003). While there is considerable scope to enhance knowledge of these two species, attention to other Tor species should be prioritised in accordance with their conservation status. For example, nothing is yet known about the basic biology and ecology of T. remadevii, despite it achieving the largest body sizes of all Tor (Pinder et al. 2018a) and being the only mahseer species assessed as 'Critically Endangered' (Pinder et al. 2018b).

The application of aquatic telemetry technologies as a bio-surveillance tool is still in its infancy across mahseer range countries (Baras et al. 2002). Research to date has been exclusively limited to the Manas watershed in Bhutan, but has revealed fascinating insight to the movements of $T$. putitora, with upstream movements of $30 \mathrm{~km}$ and elevation gains of $200 \mathrm{~m}$ recorded within single $24 \mathrm{~h}$ periods (J. Claussen pers. comm.). While some records suggest that the elevation range of $T$. putitora extends to a maximum of $1800 \mathrm{~m}$ in India (Cordington 1946) and $2100 \mathrm{~m}$ in Nepal (Shrestha 1997) in-country development of skills will be critical to accelerate the knowledge gain required to validate these observations, quantify natural home ranges and the functional habitat utilisation of all Tor spp. across a 
representative range of watersheds. These data will be of fundamental importance to schemes aiming to restore river connectivity for populations impacted by impoundment ( $c f$. Restoration of river connectivity).

Dynamic shifts in physiological and morphological development and corresponding organism/ microhabitat associations during early development remain a poorly researched component of life history in fishes (Browman and Skiftesvik 2014). Despite representing the most critical life history period and, thus, key to regulating recruitment success (Fuiman and Higgs 1997), such detail is often overlooked due to perceived challenges associated with capture and identification of larval and juvenile cyprinids (Pinder 2001). While some mahseer habitat has already been lost, most remaining populations are subject to variable but escalating degrees of habitat deterioration. With migratory access frequently compromised or blocked by instream engineering projects and the associated shift from lotic to vast expanses of lentic habitat, understanding the adaptive plasticity of species throughout their entire ontogenetic ecology will be critical in order to assess population resilience to the joint threats of anthropogenic re-engineering of rivers and climate change. Without such knowledge, evidence-based input to Environmental Impact Assessment (EIA), understanding and predicting the mechanistic risks of climate change, and future species conservation planning will remain severely compromised.

\section{Conclusions}

To date, the taxonomy across the genus Tor has been confused and a key factor identified in constraining extinction risk assessment and the development of effective species conservation planning. At the time of writing, FishBase continued to list 50 different species of Tor of which 23 were suggested to be valid (Froese and Pauly 2018). Incorporating recent species descriptions, examining the validity of synonymies and extensive literature review, the revision of the number of currently valid species to 16 , represents a comprehensive overhaul of the genus and a long overdue baseline on which to build further knowledge. With new species descriptions anticipated from less studied regions and the emergence of evidence to challenge former assumptions of species con- specificity also expected, this dynamic state of knowledge means regular conservation reassessments will be essential to prioritise research focus and facilitate effective conservation planning. While this paper presents a synthesis of population threats and opportunities to conserve these freshwater icons, their future security rests in the hands of local and regional biodiversity managers and policy-makers, and critically relies on a shift from piecemeal reactive to proactive multidisciplinary conservation planning.

Acknowledgements We wish to thank A. J. T. Johnsingh, D. D'Souza, A. Nair, M. Dhillon, S. Chakrabarty, N. Sreenivisan, S. Philip, S. Saxena, P. Srivastava and A. Manimekalan for their contribution of knowledge, field support and access to rivers and Tor specimens. We are grateful to R. Britz and O. Crimmen at the Natural History Museum, London, and S. J. Srinivasa at Mysore Natural History Museum, Mysore, India for facilitating access to specimens. We thank V. Talwar, V. Vishwasrao and Y. Kulkarni of Tata Power for facilitating enlightening stakeholder workshops, and T. Disdale and M. Clark and A. Clark of the Trans World Fishing Team for the provision of historic photographs. T. Roberts, B. A. Laskar and H. D. Hoang kindly contributed specimen images and R. Philpott assisted with image processing. R Bhatnagar, Chief Conservator of Forests, Udaipur, promoted the Lake Badi mahseer reserve and provided documentation.

Open Access This article is distributed under the terms of the Creative Commons Attribution 4.0 International License (http:// creativecommons.org/licenses/by/4.0/), which permits unre stricted use, distribution, and reproduction in any medium, provided you give appropriate credit to the original author(s) and the source, provide a link to the Creative Commons license, and indicate if changes were made.

\section{References}

Alós J, Palmer M, Arlinghaus R (2012) Consistent selection towards low activity phenotypes when catchability depends on encounters among human predators and fish. PLoS ONE 7:e48030

Ambak MA, Isa MM, Zakaria MZ, Ghaffar MA (eds) (2012) Fishes of Malaysia, 2nd edn. Penerbit UMT, Terengganu, MY

Arai R (2011) Fish Karyotypes: A Check List. Springer, Tokyo

Arlinghaus R, Cooke SJ (2009) Recreational Fishing: Socioeconomic importance, Conservation issues and Management challenges. In: Dickson B, Hutton J, Adams B (eds) Recreational Hunting, Conservation and Rural Livelihoods: Science and Practice. Blackwell, Oxford, pp 39-58

Arlinghaus R, Cooke SJ, Lyman J, Policanksy D, Schwab A, Suski C, Sutton SG, Thorstad EB (2007) Understanding the complexity of catch-and-release in recreational fishing: an integrative synthesis of global knowledge from 
historical, ethical, social and biological perspectives. Rev Fish Sci 15:75-167

Arlinghaus R, Matsumura S, Dieckmann U (2010) The conservation and fishery benefits of protecting large pike (Esox lucius L.) by harvest regulations in recreational fishing. Biol Conserv 143:1444-1459

Arlinghaus R, Schwab A, Riepe C, Teel T (2012) A primer on anti-angling philosophy and its relevance for recreational fisheries in urbanized societies. Fisheries 37:153-164

Arlinghaus R, Tillner R, Bork M (2015) Explaining participation rates in recreational fishing across industrialised countries. Fish Manag Ecol 22:45-55

Arlinghaus R, Cooke SJ, Sutton SG, Danylchuk AJ, Potts W, Freire K, Alos J, da Silva ET, Anrooy R (2016) Recommendations for the future of recreational fisheries to prepare the social-ecological system to cope with change. Fish Manag Ecol 23:177-186

Arlinghaus R, Alós J, Beardmore B, Daedlow K, Dorow M, Fujitani M, Huhn D, Haider W, Hunt LM, Johnson BM, Johnston F, Klefoth T, Matsumura S, Monk C, Pagel T, Post JR, Rapp T, Riepe C, Ward H, Wolter C (2017) Understanding and managing freshwater recreational fisheries as complex adaptive social-ecological systems. Rev Fish Sci Aquac 25:1-41

Arthington AH, Dulvy NK, Gladstone W, Winfield IJ (2016) Fish conservation in freshwater and marine realms: status, threats and management. Aquat Conserv 26:838-857

Arunkumar L, Basudha C (2003) Tor barakae, a new species of mahseer fish (Cyprinidae: Cyprininae) from Manipur, India. Aquaculture 4:271-276

Baras E, Bénech V, Marmulla G (2002) Outcomes of a pilot fish telemetry workshop for developing countries. Hydrobiology 483:9-11

Barnes MA, Turner CR, Jerde CL, Renshaw MA, Chadderton WL, Lodge DM (2014) Environmental conditions influence eDNA persistence in aquatic systems. Environ Sci Technol 48:1819-1827

Barnett A, Abrantes KG, Baker R, Diedrich AS, Farr M, Kuilboer A, Mahony T, McLeod I, Moscardo G, Prideaux M, Stoeckl N, van Luyn A, Stoeckl N (2016) Sportfisheries, conservation and sustainable livelihoods: a multidisciplinary guide to developing best practice. Fish Fish 17:696-713

Bartholomew A, Bohnsack JA (2005) A review of catch-andrelease angling mortality with implications for no-take reserves. Rev Fish Biol Fish 15:129-154

Belcher WR (1998) Fish exploitation of the Baluchistan and Indus Valley Traditions: an ethnoarchaeological approach to the study of fish remains-William $\mathrm{R}$ Belcher (University of Wisconsin-Madison)

Bhagwat SA, Rutte C (2006) Sacred groves: potential for biodiversity management. Front Ecol Environ 4:519-524

Bhatt JP, Pandit MK (2016) Endangered Golden mahseer Tor putitora Hamilton: a review of natural history. Rev Fish Biol Fish 26:25-38

Birnie-Gauvin K, Franklin P, Wilkes M, Aarestrup K (2018) Moving beyond fitting fish into equations: Progressing the fish passage debate in the Anthropocene. In Press, Aquat Conserv

Bishop JE (1973) Limnology of a small Malayan River-Sungai Gombak. Junk Publisher, The Hague, Dr, p 485p
Bleeker P (1854) Overzigt der ichthyologische fauna van Sumatra, met beschrijving van eenige nieuwe soorten. Natuurkundig tijdschrift voor Nederlandsch Indië 7:49108

Bleeker P (1863) Atlas ichthyologique des Indes Orientales Neerlandaises. Tome Ill. Cyprins. Frederic Muller, Amsterdam

Bower SD, Nguyen VM, Danylchuk AJ, Beard Jr TD, Cooke SJ (2014) Inter-sectoral conflict and recreational fisheries of the developing world: Opportunities and challenges for co-operation. In: McConney P, Medeiros R, Pena M (eds) Enhancing stewardship in small-scale fisheries: practices and perspectives, pp 88-97. Barbados: CERMES Technical Report No. 73

Bower SD, Danylchuk AJ, Raghavan R, Clark-Danylchuk SE, Pinder AC, Cooke SJ (2016) Rapid assessment of the physiological impacts caused by catch-and-release angling on blue-finned mahseer (Tor sp.) of the Cauvery River, India. Fish Manag Ecol 23:208-217

Bower SD, Danylchuk AJ, Raghavan R, Danylchuk SC, Pinder AC, Alter AM, Cooke SJ (2017) Involving recreational fisheries stakeholders in development of research and conservation priorities for mahseer (Tor spp.) of India through collaborative workshops. Fish Res 186:665-671

Browman HI, Skiftesvik AB (2014) The early life history of fish-there is still a lot of work to do! ICES J Mar Sci 71:907-908

Caro T (2010) Conservation by proxy: indicator, umbrella, keystone, flagship, and other surrogate species. Island Press

CBD (Undated) The Convention on Biological Diversity. https://www.cbd.int/convention. Accessed 08 Mar 2019

Ceylon Fishing Club (1925) Report for the year November, 1924-October, 1925

Chen ZM, Yang JX (2004) A new species of the genus Tor from Yunnan, China (Teleostei: Cyprinidae). Environ Biol Fish 70:185-191

Closs GP, Krkosek M, Olden JD (2016) Synthesis-what is the future of freshwater fishes? In Closs GP, Krkosek M, Olden JD (eds) Conservation of freshwater fishes. University Press, Cambridge, vol 99, pp 563-572

Cooke SJ, Suski CD (2005) Do we need species-specific guidelines for catch-and-release recreational angling to effectively conserve diverse fishery resources? Biodivers Conserv 14:1195-1209

Cooke SJ, Arlinghaus R, Johnson BM, Cowx IG (2016a) Recreational fisheries in inland waters. In: Craig JF (ed) Freshwater Fisheries Ecology. Wiley Blackwell, Oxford, pp 449-465

Cooke SJ, Hogan ZS, Butcher PA, Stokesbury MJ, Raghavan R, Gallagher AJ, Hammerschlag N, Danylchuk AJ (2016b) Angling for endangered fish: conservation problem or conservation action? Fish Fish 17:249-265

Cooke SJ, Twardek WM, Lennox RJ, Zolderdo AJ, Bower SD, Gutowsky LF, Danylchuk AJ, Arlinghaus R, Beard D (2018) The nexus of fun and nutrition: recreational fishing is also about food. Fish Fish 19:201-224

Cordington KDeB (1946) Notes on Indian Mahseer. J Bombay Nat History Soc 46:334-336

Cuvier G, Valenciennes A (1842) Histoire naturelle des Poissons, vol 16. Paris 
CWC (2017) National register of large dams. Central Water Commission, Pune. http://cwc.gov.in/national-registerlarge-dams. Accessed 25 Jan 2017

Dahanukar N (2011) Tor kulkarnii. The IUCN Red List of Threatened Species 2011: e.T172355A6875134. http:// dx.doi.org/10.2305/IUCN.UK.2011-1.RLTS. T172355A6875134.en. Accessed 13 Mar 2019

Dahanukar N, Katwate U, Pinder A, Harrison A (2018a) Tor kulkarnii. The IUCN red list of threatened species 2018: e. T172355A60609857. http://dx.doi.org/10.2305/IUCN. UK.2018-2.RLTS.T172355A60609857.en. Accessed 13 Mar 2019

Dahanukar N, Pinder A, Harrison A (2018b) Tor mosal. The IUCN red list of threatened species 2018: e. T188106A1855151. http://dx.doi.org/10.2305/IUCN.UK. 2018-2.RLTS.T188106A1855151.en. Accessed 13 Mar 2019

Dandekar P (2011a) India's community fish sanctuaries protect wild fish and rivers. World River Rev 26:1-7

Dandekar P (2011b) Temple fish sanctuaries: Last bastions of native fish and pristine river stretches - a report. http:// www.indiawaterportal.org/articles/temple-fish-sanctuar ies-last-bastions-native-fish-and-pristine-river-stretches-re port. Accessed 21 Sept 2018

Darwall WR, Freyhof J (2016) Lost fishes, who is counting? The extent of the threat to freshwater fish biodiversity. In: Closs GP, Krkosek M, Olden JD (eds) Conservation of freshwater fishes. University Press, Cambridge, pp 1-36

Davidson NC (2014) How much wetland has the world lost? Long-term and recent trends in global wetland area. Mar Freshw Res 65:934-941

Davison PI, Créach V, Liang WJ, Andreou D, Britton JR, Copp GH (2016) Laboratory and field validation of a simple method for detecting four species of non-native freshwater fish using eDNA. J Fish Biol 89:1782-1793

Day F (1876) On some of the Fishes of the Deccan. J Linn Soc Lond Zool 12:565-578

De Jalon DG, Sanchez P, Camargo JA (1994) Downstream effects of a new hydropower impoundment on macrophyte, macroinvertebrate and fish communities. Regul River 9:253-261

Department of Fisheries, Ceylon (1958) A guide to the fisheries of Ceylon-Bulletin No. 8. Publication of the Fish Res Station, Ceylon

Desai VR (2003) Synopsis of biological data on the Tor mahseer, Tor tor (Hamilton, 1822). FAO Fisheries Synopsis, 158

Dhu S (1923) The angler in India or the mighty mahseer. Natraj, Dehra Dun

Dudgeon D (2000) Large-scale hydrological changes in Tropical Asia: prospects for riverine biodiversity: the construction of large dams will have an impact on the biodiversity of tropical Asian rivers and their associated wetlands. Bioscience 50:793-806

Dudgeon D (2011) Asian river fishes in the Anthropocene: threats and conservation challenges in an era of rapid environmental change. J Fish Biol 79:1487-1524

Dudgeon D, Arthington AH, Gessner MO, Kawabata ZI, Knowler DJ, Lévêque C, Naiman J, Prieur-Richard A, Soto D, Stiassny J, Sullivan CA (2006) Freshwater biodiversity: importance, threats, status and conservation challenges. Biol Rev 81:163-182

Esa Y, Siraj SS, Daud SK, Rahim KAA, Abdullah MT, Japning JRR, Tan SG (2006) Mitochondrial DNA diversity of Tor douronensis Valenciennes (Cyprinidae) in Malaysian Borneo. Pertan J Trop Agric Sci 29:47-55

Eschmeyer WN, Fong JD (2016) Catalog of fishes. http:// www.calacademy.org/scientists/projects/catalog-of-fishes. Accessed 21 Sept 2018

Eschmeyer WN, Fricke R, van der Laan R (2017) Catalog of Fishes, electronic version (3 January 2017). CA (California Academy of Sciences), San Francisco

Evans BJ, Kelley DB, Melnick DJ, Cannatella DC (2005) Evolution of RAG-1 in polyploid clawed frogs. Mol Biol Evol 22:1193-1207

Everard M (2013) The Hydropolitics of Dams: Engineering or Ecosystems?. Zed Books, London

Everard M, Kataria G (2011) Recreational angling markets to advance the conservation of a reach of the Western Ramganga River. Aquat Conserv 21:101-108

Everard M, Fletcher M, Powell A, Dobson M (2011) The feasibility of developing multi-taxa indicators for freshwater wetland systems. Freshw Rev 4:1-19

Everard M, Sharma OP, Vishwakarma VK, Khandal D, Sahu YK, Bhatnagar R, Kumar V, Nawab A, Kumar A, Kumar V, Kashyap A, Pandey DN, Pinder AC (2018) Assessing the feasibility of integrating ecosystem-based with engineered water resource governance and management for water security in semi-arid landscapes: a case study in the Banas catchment, Rajasthan, India. Sci Total Environ 612:1249-1265

FAO (2012) Recreational fisheries. Technical Guidelines for Responsible Fisheries. No. 13. Rome, FAO

Fedler AJ (2000) Participation in boating and fishing: a literature review. Report of human dimensions consulting to the recreational boating and fishing foundation. Alexandria, Virginia, USA

Fedler AJ, Ditton RB (1994) Understanding angler motivations in fisheries management. Fisheries 19:6-13

Ferguson JW, Healey M, Dugan P, Barlow C (2011) Potential effects of dams on migratory fish in the Mekong River: lessons from salmon in the Fraser and Columbia Rivers. Environ Manage 47:141-159

Finlayson CM, Davidson N, Fennessy S, Coates, D, Gardner RC, with contributing authors Darwall W, Dema M, Everard M, McRae L, Perennou C, Stroud D (2018) Section 2: status and trends. In: Gardner RC, Finlayson CM (eds) Global wetland outlook: state of the world's wetlands and their services to people. Gland, Switzerland: Ramsar Convention Secretariat

Forest Department (2018) Mahseer conservation reserve, Badi Lake, Udaipur. Forest Department, Udaipur

Froese R, Pauly D (2018) FishBase. World Wide Web electronic publication. www.fishbase.org, version (02/2019)

Fuiman LA, Higgs DM (1997) Ontogeny, growth and the recruitment process. In: Chambers RC, Trippel EA (eds) Early Life History and Recruitment in Fish Populations. Springer, Dordrecht

Gadgil M (1991) Conserving India's biodiversity: the societal context. Evol Trend Plant 5:3-8 
Granek EF, Madin EMP, Brown MA, Figueira W, Cameron DS, Hogan Z, Kristianson G, De Villiers P, Williams JE, Post J, Zahn S, Arlinghaus R (2008) Engaging recreational fishers in management and conservation: global case studies. Conserv Biol 22:1125-1134

Greenberg SA (2009) How citation distortions create unfounded authority: analysis of a citation network. BMJ 339: b2680

Grumbine RE, Pandit MK (2013) Threats from India's Himalaya dams. Science 339:36-37

Gupta N, Everard M (2017) Non-native fishes in the Indian Himalaya: an emerging concern for freshwater scientists. Int J River Basin Manag 15:1-5

Gupta N, Raghavan R, Sivakumar K, Mathur VB (2014) Freshwater fish safe zones: a prospective conservation strategy for river ecosystems in India. Curr Sci India 107:949-950

Gupta N, Raghavan R, Sivakumar K, Mathur V, Pinder AC (2015) Assessing recreational fisheries in an emerging economy: knowledge, perceptions and attitudes of catchand-release anglers in India. Fish Res 165:79-84

Gupta N, Kanagavel A, Dandekar P, Dahanukar N, Sivakumar K, Mathur VB, Raghavan R (2016) God's fishes: religion, culture and freshwater fish conservation in India. Oryx 50:244-249

Gurung TB, Rai AK, Joshi PL (2002) Breeding of pond reared golden mahseer (Tor putitora) in Pokhara, Nepal. In: Cold water fisheries in the trans-Himalayan countries. FAO Fisheries Technical Paper, vol 431, pp 147-160

Hamilton F (1822) An account of the fishes found in the river Ganges and its branches. Edinburgh (1981) Bishan Singh Mahendra Pal Singh. Dehradun, India

Hänfling B, Lawson Handley L, Read DS, Hahn C, Li J, Nichols P, Blackman RC, Oliver A, Winfield IJ (2016) Environmental DNA metabarcoding of lake fish communities reflects long-term data from established survey methods. Mol Ecol 25:3101-3119

Hoang HD, Pham HM, Durand JD, Tran NT, Phan PĐ (2015) Mahseers genera Tor and Neolissochilus (Teleostei: Cyprinidae) from southern Vietnam. Zootaxa 4006:551568

Hora SL (1939) The game fishes of India III: the mahseer or the large scaled barbels of India. 1. The putitor mahseer Barbus (Tor) putitora Hamilton. J Bombay Nat Hist Soc 41:272-285

Hora SL (1940) The game fishes of India IX. The mahseer or the large scaled barbels of India 2. The tor mahseer, Barbus (Tor) tor (Hamilton). J Bombay Nat Hist Soc 41:518-525

Hora SL (1942) The game fishes of India xv. The Mahseers or large-scaled Barbels of India 8. On the specific identity of Syke's species of Barbus from the Deccan. J Bombay Nat Hist Soc 42:163-169

Hora SL (1943) The game fishes of India XVII. The mahseers or the large-scaled barbels of India 10. On the specific identity of Jerdon's species of mahseer from Southern India. J Bombay Nat Hist Soc 44:164-168

Hora SL (1951) A Sanskrit work on angling of the early twelfth century. Nature 167:778
Hora SL (1953) Knowledge of ancient Hindus concerning Fish Fish of India 4. Fish in Sutras and Smriti literature. J R Asiat Soc Bengal Lett 110:63-77

Hora SL (1956) Fish paintings of the third millennium B.C. from $\mathrm{Nal}$ (Baluchistan) and their zoogeographical significance. Mem Indian Mus Kolkata 14:78-84

Huckstorf V, Pinder A, Harrison A (2018) Tor polylepis. The IUCN Red List of Threatened Species 2018: e. T188025A126323203. http://dx.doi.org/10.2305/IUCN. UK.2018-2.RLTS.T188025A126323203.en. Accessed 13 Mar 2019

Hunt LM, Sutton SG, Arlinghaus R (2013) Illustrating the critical role of human dimensions research for understanding and managing recreational fisheries within a social-ecological system framework. Fish Manag Ecol 20 (2-3):111-124

ICIMOD (2009) The Changing Himalayas: Impact of climate change on water resources and livelihoods in the Greater Himalayas. ICIMOD, Lalitpur

Indra TJ (1993) Report on the ichthyofauna of Kanyakumari District, Tamil Nadu. Rec Zool Surv India 92:177-192

Ingram B, Sungan S, Gooley G, Sim SY, Tinggi D, De Silva SS (2005) Induced spawning, larval development and rearing of two indigenous Malaysian mahseer, Tor tambroides and T. douronensis. Aquac Res 36:983-995

Ingram B, Sungan S, Tinggi D, Sim SY, De Silva SS (2007) Breeding performance of Malaysian mahseer, Tor tambroides and T. douronensis broodfish in captivity. Aquac Res 38:809-818

IUCN (2012) IUCN Red List Categories and Criteria: Version 3.1. Second edition. Gland, Switzerland and Cambridge, UK: IUCN

IUCN (2018) The IUCN red list of threatened species. Version 2018.2. http://www.iucnredlist.org

IUCN Standards and Petitions Subcommittee (2017) Guidelines for using the IUCN Red List Categories and Criteria. Version 13

Jadhav U (2009) Aquaculture technology and environment. PHI Learning Pvt. Ltd., pp 21-22

Jayaram KC (1995) The Krishna river system: a bioresources study. Records of Zoological Society of India Occasional Paper No. 160

Jayaram KC (1997) Massacre of mahseer fish. Curr Sci India 72:901

Jayaram KC (1999) The freshwater fishes of the Indian region. Narendra Publishing House, Delhi

Jayaram KC (2005) The Deccan mahseer fishes: their ecostatus and threat percepts. Rec Zool Surv India 238:1-102

Jayaram KC (2010) The Freshwater Fishes of the Indian Region. Narendra Publishing House, Delhi

Jensen OP, Gilroy DJ, Hogan Z, Allen BC, Hrabik TR, Weidel BC, Chandra S (2009) Evaluating recreational fisheries for an endangered species: a case study of taimen, Hucho taimen, in Mongolia. Can J Fish Aquat Sci 66:1707-1718

Jerde CL, Mahon AR, Chadderton WL, Lodge DM (2011) "Sight-unseen" detection of rare aquatic species using environmental DNA. Conserv Lett 4:150-157

Jerdon TC (1849) On the fresh-water fishes of southern India. Madras J Lit Sci 15:302-346

Jha BR, Rayamajhi A, Dahanukar N, Harrison A, Pinder A (2018) Tor putitora. The IUCN red list of threatened 
species 2018: e.T126319882A126322226. http://dx.doi. org/10.2305/IUCN.UK.2018-2.RLTS.T126319882A1263 22226.en. Accessed 13 Mar 2019

Johnson PTJ, Olden JD, Vander Zanden MJ (2008) Dam invaders: impoundments facilitate biological invasions into freshwaters. Front Ecol Environ 6:357-363

Johnston FD, Beardmore B, Arlinghaus R (2014) Optimal management of recreational fisheries in the presence of hooking mortality and noncompliance-predictions from a bioeconomic model incorporating a mechanistic model of angler behaviour. Can J Fish Aquat Sci 72:37-53

Joppa LN, Pfaff A (2009) High and far: biases in the location of protected areas. PLoS ONE 4(12):e8273

Jorgensen C, Enberg K, Dunlop ES, Arlinghaus R, Boukal DS, Brander K, Ernande B, GErdmark A, Johnston F, Matsumura S, Pardoe H, Raab K, Silva A, Vainikka A, Dieckmann U, Heino M, Rijnsdorp AD (2007) Ecologymanaging evolving fish stocks. Science 318:1247-1248

Joshi PL, Gurung TB, Basnyat SR, Nepal AP (2002) Domestication of wild golden mahseer (Tor putitora) and hatchery operation. In: Cold water fisheries in the transHimalayan countries. FAO Fisheries Technical Paper vol 431, pp 173-178

Juffe-Bignoli D, Burgess ND, Bingham H, Belle EMS, de Lima MG, Deguignet M, Bertzky B, Milam AN, Martinez-Lopez J, Lewis E, Eassom A, Wicander S, Geldmann J, van Soesbergen A, Arnell AP, O'Connor B, Park S, Shi YN, Danks FS, MacSharry B, Kingston N (2014) Protected planet report 2014. Cambridge, UK, UNEP-WCMC

Katwate C, Pawar R, Shinde V, Apte D, Katwate U (2014) How long will social beliefs protect the pride of River Savitri? MIN: The Newsletter of the IUCN SSC/WI Freshwater Fish Specialist Group (South Asia) vol 2, pp 21-24

Keller VD, Williams RJ, Lofthouse C, Johnson AC (2014) Worldwide estimation of river concentrations of any chemical originating from sewage-treatment plants using dilution factors. Environ Toxicol Chem 33:447-452

Kemp PS, O'hanley JR (2010) Procedures for evaluating and prioritising the removal of fish passage barriers: a synthesis. Fish Manag Ecol 17:297-322

Khaironizam MZ, Zakaria-Ismail M, Armbruster JW (2015) Cyprinid fishes of the genus Neolissochilus in Peninsular Malaysia. Zootaxa 3962:139-157

Kharat SS, Dahanukar N, Raut R, Mahabaleshwarkar M (2003) Long term changes in freshwater fish species composition in north Western Ghats, Pune District. Curr Sci India 84:816-820

Khare P, Mohindra V, Barman AS, Singh RK, Lal KK (2014) Molecular evidence to reconcile taxonomic instability in mahseer species (Pisces: Cyprinidae) of India. Org Divers Evol 14:307-326

Kohli MPS, Ayyappan S, Ogale SN, Langer RK, Prakash C, Dube K, Reddy AK, Patel MB, Saharan N (2002) Observations on the performance of Tor khudree in floating cages in open waters. Appl Fish Aquac 2:51-57

Kottelat M (2000) Notes on taxonomy, nomenclature and distribution of some fishes of Laos. J South Asian Nat His 5:83-90

Kottelat M (2001) Fishes of laos. Wildlife Heritage Trust, Colombo
Kottelat M (2013) The fishes of the inland waters of Southeast Asia: a catalogue and core bibliography of the fishes known to occur in freshwaters, mangroves and estuaries. Raffles Bull Zool 27:1-663

Kottelat M (2016) The fishes of the Nam Theun and Xe Bangfai drainages, Laos. Hydroécologie Appliquée 19:271-320

Kottelat M (2018) Tor laterivittatus. The IUCN red list of threatened species 2018: e.T187921A126323049. http:// dx.doi.org/10.2305/IUCN.UK.2018-2.RLTS.T187921A12 6323049.en. Accessed 13 Mar 2019

Kottelat M, Baird IG, Kullander SO, Ng HH, Parenti LR, Rainboth WJ, Vidthayanon C (2012) The status and distribution of freshwater fishes of Indo Burma. In: Allen DJ, Smith KG, Darwall WRT (eds) The status and distribution of freshwater biodiversity in Indo-Burma, pp 38-65, International Union for Conservation of Nature [IUCN]. Cambridge and Gland

Kottelat M, Pinder A, Harrison A (2018a) Tor ater. The IUCN red list of threatened species 2018: e.T188038A126323308. http://dx.doi.org/10.2305/IUCN.UK.2018-2.RLTS.T188038 A126323308.en. Accessed 13 Mar 2019

Kottelat M, Pinder A, Harrison A (2018b) Tor tambra. The IUCN red list of threatened species 2018: e.T188012A89801879. http://dx.doi.org/10.2305/IUCN.UK.2018-2.RLTS.T188012A 89801879.en. Accessed 27 Mar 2019

Kottelat M, Pinder A, Harrison A (2018c) Tor tambroides. The IUCN red list of threatened species 2018: e.T187939 A91076554. http://dx.doi.org/10.2305/IUCN.UK.2018-2.RL TS.T187939A91076554.en. Accessed 13 Mar 2019

Kulkarni CV (1971) Spawning habits, eggs and early development of Deccan mahseer, Tor khudree (Sykes). J Bombay Nat Hist Soc 67:510-521

Kulkarni CV, Ogale SN (1978) The present status of mahseer (fish) and artificial propagation of Tor khudree (Sykes). J Bombay Nat Hist Soc 75:651-660

Kumar R, Singh M, Kushwaha B, Nagpure NS, Mani I, Lakra WS (2013) Molecular characterization of major and minor rDNA repeats and genetic variability assessment in different species of mahseer found in North India. Gene 527:248-258

Kurup BM, Radhakrishnan KV (2007) Tor remadevii, a new species of mahseer from Kerala (South India), and distribution and abundance of Tor spp. the river systems of Kerala. In Siraj SS, Christianus A, Kiat NC, De Silva SS (eds) Mahseer, the biology, culture and conservation. In: Proceedings of the international symposium on the Mahseer, 29th to 30th March 2006, Kuala Lumpur, Malaysia. Kuala Lumpur: Malaysian Fisheries Society

Kurup BM, Radhakrishnan KV (2010) Tor remadevii, a new species of Tor (gray) from Chinnar Wildlife Sanctuary, Pambar River, Kerala, Southern India. J Bombay Nat Hist Soc 107:227-230

Lacoursière-Roussel A, Côté G, Leclerc V, Bernatchez L (2016) Quantifying relative fish abundance with eDNA: a promising tool for fisheries management. J Appl Ecol 53:1148-1157

Lakra WS, Sarkar UK, Gopalakrishnan A, Pandian AK (2010) Threatened freshwater fishes of India. National Bureau of Fish Genetics Resources (NBFGR) Publication, Lucknow, India

Lal KK, Singh RK, Pandey A, Gupta BK, Mohindra V, Punia P, Dhawan S, Verma J, Tyagi LK, Khare P, Jena JK 
(2013) Distributional records of Tor mahseer Tor tor (Hamilton, 1822) from Southern India. J Appl Ichthyol 29:1086-1090

Laskar BA, Bhattacharjee MJ, Dhar B, Mahadani P, Kundu S, Ghosh SK (2013) The species dilemma of northeast Indian mahseer (Actinopterygii: Cyprinidae): DNA barcoding in clarifying the riddle. PLoS ONE 8:e53704

Laskar BA, Kumar V, Kundu S, Tyagi K, Chandra K (2018) Taxonomic quest: validating two mahseer fishes (Actinopterygii: Cyprinidae) through molecular and morphological data from biodiversity hotspots in India. Hydrobiologia 815:113-124

Lawson-Handley L (2015) How will the 'molecular revolution' contribute to biological recording? Biol J Lin Soc 115:750-766

Lester NP, Shuter BJ, Venturelli P, Nadeau D (2014) Lifehistory plasticity and sustainable exploitation: a theory of growth compensation applied to walleye management. Ecol Appl 24:38-54

MacDonald ASJ (1948) Circumventing the Mahseer. Natraj, Dehra Dun

Mani I, Kumar R, Singh M, Kushwaha B, Nagpure NS, Srivastava PK, Lakra WS (2009) Karyotypic diversity and evolution of seven mahseer species (Cyprinidae) from India. J Fish Biol 75:1079-1091

Menon AGK (1992) Taxonomy of the Mahseer fishes of genus Tor Gray with description of new species from Deccan. J Bombay Nat Hist Soc 89:210-228

Menon AGK (1999) Checklist of freshwater fishes of India. Rec Zool Surv India 175:56-57

Menon AGK (2004) Threatened Fishes of India and their Conservation. Zoological Survey of India, Kolkata, p 170

Mohindra V, Khare P, Lal KK, Punia P, Singh RK, Barman AS, Lakra WS (2007) Molecular discrimination of five Mahseer species from Indian peninsula using RAPD analysis. Acta Zool Sin 53:725-732

Mohsin AM, Ambak MA (1983) Freshwater fishes of peninsular Malaysia. Penerbit Universiti Pertanian Malaysia

Muoneke MI, Childress WM (1994) Hooking mortality: a review for recreational fisheries. Rev Fish Sci 2:123-156

Naiman R (2013) Socio-ecological complexity and the restoration of river ecosystems. Inl Waters 3:391-410

Nautiyal P (2014) Review of the art and science of Indian Mahseer (Game fish) from nineteenth to twentieth century: road to extinction or conservation? Proc Natl Acad Sci India Sect B Biol Sci 84:215-236

Nautiyal P, Bahuguna SN, Thapliyal RP (2001) The role of ecological factors in governing the direction, time and purpose of migration in Himalayan Mahseer Tor putitora (Ham.). Appl Fish Aquac 1:133-138

Nautiyal P, Rizvi AF, Dhasmanaa P (2008) Life History traits and decadal trends in the growth parameters of Golden Mahseer, Tor putitora (Hamilton 1822) from the Himalayan stretch of the Ganga River System. Turk J Fish Aquat Sc 8:125-132

Ng CK (2004) Kings of the River-Mahseer in Malaysia and the region. Inter Sea Fishery (M), Kuala Lumpur, Malaysia

Nguyen TT, Na-Nakorn U, Sukmanomon S, ZiMing C (2008) A study on phylogeny and biogeography of mahseer species (Pisces: Cyprinidae) using sequences of three mitochondrial DNA gene regions. Mol Phylogenet Evol 48:1223-1231

Norfatimah MY, Teh LK, Salleh MZ, Isa MM, SitiAzizah MN (2014) Complete mitochondrial genome of Malaysian Mahseer (Tor tambroides). Gene 548:263-269

Ogale SN (1997) Induced spawning and hatching of golden mahseer Tor putitora (Hamilton) at Lonavla, Pune District (Maharashtra) in Western Ghats. Fishing Chimes, pp 27-29

Ogale SN (2002) Mahseer breeding and conservation and possibilities of commercial culture. The Indian experience. In: Cold water fisheries in the trans-Himalayan countries. FAO Fisheries Technical Paper 431, pp 193-212

Ogale SN, Kulkarni CV (1987) Breeding of pond-raised hybrids of Mahseer Fish, Tor Khudree (Sykes) and T. tor (Ham.). J Bombay Nat Hist Soc 84:332-335

Ovidio M, Philippart JC (2002) The impact of small physical obstacles on upstream movements of six species of fish. Hydrobiologia 483:55-69

Pathani SS, Das SM (1979) On induced spawning of mahseer Tor putitora (Hamilton) by mammalian and fish pituitary hormone injection. Sci Cult 45:209-210

Peh KSH (2010) Invasive species in Southeast Asia: the knowledge so far. Biodivers Conserv 19:1083-1099

Pelayo-Villamil P, Guisande C, Vari RP, Manjarrés-Hernández A, García-Roselló E, González-Dacosta J, Heine J, González Vilas L, Patti B, Quinci EM, Jiménez LF, GranadoLorencio C, Tedesco PA, Lobo JM (2015) Global diversity patterns of freshwater fishes-potential victims of their own success. Divers Distrib 21:345-356

Pinder AC (2001) Keys to larval and juvenile stages of coarse fishes from fresh waters in the British Isles. Scientific Publication No. 60. Freshwater Biological Association, Ambleside

Pinder AC (2015) Icon of the Cauvery. Sanctuary Asia, October 2015, pp 50-53

Pinder A (2018) Tor yingjiangensis. The IUCN red list of threatened species 2018:e.T188067A1850734. http:// dx.doi.org/10.2305/IUCN.UK.2018-2.RLTS.T188067A18 50734.en. Accessed 13 Mar 2019

Pinder A, Harrison A (2018) Tor dongnaiensis. The IUCN red list of threatened species 2018: e.T126318880A12 6323439. http://dx.doi.org/10.2305/IUCN.UK.2018-2.RL TS.T126318880A126323439.en. Accessed 13 Mar 2019

Pinder AC, Raghavan R (2013) Conserving the endangered Mahseers (Tor spp.) of India: the positive role of recreational fisheries. Curr Sci India 104:1472-1475

Pinder AC, Raghavan R, Britton JR (2015a) Efficacy of angler catch data as a population and conservation monitoring tool for the flagship Mahseer fishes (Tor spp.) of Southern India. Aquat Conserv 25:829-838

Pinder AC, Raghavan R, Britton JR (2015b) The legendary hump-backed mahseer Tor sp. of India's River Cauvery: an endemic fish swimming towards extinction? Endanger Species Res 28:11-17

Pinder AC, Manimekalan A, Knight JDM, Krishnankutty P, Britton JR, Philip S, Dahanukar N, Raghavan R (2018a) resolving the taxonomic enigma of the iconic gamefish, the hump-backed mahseer from the Western Ghats hotspot, India. Plos One 13(6):e0199328

Pinder A, Katwate U, Dahanukar N, Harrison A (2018b) Tor remadevii. The IUCN red list of threatened species 2018: 
e.T56096394A56717605. http://dx.doi.org/10.2305/IUC N.UK.2018-2.RLTS.T56096394A56717605.en. Accessed 13 Mar 2019

Poff NL, Schmidt JC (2016) How dams can go with the flow. Science 353:1099-1100

Poff NL, Zimmerman JK (2010) Ecological responses to altered flow regimes: a literature review to inform the science and management of environmental flows. Freshw Biol 55:194-205

Poff NL, Olden JD, Merritt DM, Pepin DM (2007) Homogenization of regional river dynamics by dams and global biodiversity implications. Proc Natl Acad Sci 104:57325737

Post JR (2013) Resilient recreational fisheries or prone to collapse? A decade of research on the science and management of recreational fisheries. Fish Manag Ecol 20:99110

Post JR, Sullivan M, Cox S, Lester NP, Walters CJ, Parkinson EA, Paul AJ, Jackson L, Shuter BJ (2002) Canada's recreational fisheries: the invisible collapse. Fisheries 27:6-17

Quinn TP, Adams DJ (1996) Environmental changes affecting the migratory timing of American shad and sockeye salmon. Ecology 77:1151-1162

Raghavan R (2013) Tor khudree. The IUCN red list of threatened species 2013: e.T169609A6653249. http://dx.doi. org/10.2305/IUCN.UK.2011-1.RLTS.T169609A6653249. en. Accessed 13 Mar 2019

Raghavan R, Ali A, Dahanukar N, Rosser A (2011) Is the Deccan Mahseer, Tor khudree (Sykes, 1839) (Pisces: Cyprinidae) fishery in the Western Ghats Hotspot sustainable? A participatory approach to stock assessment. Fish Res 110:29-38

Raghavan R, Ali, A (2013) Tor malabaricus. The IUCN red list of threatened species 2013: e.T172457A6895822. http:// dx.doi.org/10.2305/IUCN.UK.2011-1.RLTS. T172457A6895822.en. Accessed 13 Mar 2019

Raghavan R, Dahanukar N, Britz R (2017) The type locality of Tor mosal (Hamilton, 1822) (Teleostei: Cyprinidae). Zootaxa 4317:593-596

Rahman AA (1989) Freshwater fishes of Bangladesh. Zoological Society of Bangladesh

Rahman MA, Mazid MA, Rahman MR, Khan MN, Hossain MA, Hussain MG (2005) Effect of stocking density on survival and growth of critically endangered mahseer, Tor putitora (Hamilton), in nursery ponds. Aquaculture 249:275-284

Rajasthan High Court (2017) High court of judicature for Raiasthan at Jodhpur, D.B. Civil Writ Petition No. 7077/2OL4. Rajasthan High Court, 4th April 2017

Raman S, Pavan-Kumar A, Koringa PG, Patel N, Shah T, Singh RK, Krishna G, Joshi CG, Gireesh-Babu P, Chaudhari A, Lakra WS (2016) Ion torrent next-generation sequencing reveals the complete mitochondrial genome of endangered mahseer Tor khudree (Sykes, 1839). Mitochondrial DNA Part A 27:2949-2950

Ramsar Convention Secretariat (2010) Wise use of wetlands: concepts and approaches for the wise use of wetlands. Ramsar handbooks for the wise use of wetlands, 4th edition, vol. 1. Ramsar Convention Secretariat, Gland, Switzerland
Rayamajhi A, Jha BR, Sharma CM (2010) Tor tor. The IUCN red list of threatened species 2010: e.T166534A6231157. http://dx.doi.org/10.2305/IUCN.UK.2010-4.RLTS.T1665 34A6231157.en. Accessed 30 May 2017

Rayamajhi A, Jha BR, Sharma CM, Pinder A, Harrison A, Katwate U, Dahanukar N (2018) Tor tor. The IUCN red list of threatened species 2018: e.T166534A126321898. http://dx.doi.org/10.2305/IUCN.UK.2018-2.RLTS. T166534A126321898.en. Accessed 13 Mar 2018

Reid AJ, Carlson AK, Creed IF, Eliason EJ, Gell PA, Johnson PTJ, Kidd KA, MacCormack TJ, Olden JD, Ormerod SJ, Smol JP, Taylor WW, Tockner K, Vermaire JC, Dudgeon D, Cooke SJ (2018) Emerging threats and persistent conservation challenges for freshwater biodiversity. Biol Rev (in press)

Roberts TR (1993) The freshwater fishes of Java, as observed by Kuhl and van Hasselt in 1820-23. Zoologische Verhandelingen 285:1-94

Roberts TR (1999) Fishes of the cyprinid genus Tor in the Nam Theun watershed (Mekong basin) of Laos, with description of a new species. Raffles Bull Zool 47:225-236

Roberts TR, Khaironizam MZ (2008) Trophic polymorphism in the Malaysian fish Neolissochilus soroides and other old world barbs (Teleostei, Cyprinidae). Nat Hist Bull Siam Soc 56:25-53

Romão F, Quaresma AL, Branco P, Santos JM, Amaral S, Ferreira MT, Katopodis C, Pinheiro AN (2017) Passage performance of two cyprinids with different ecological traits in a fishway with distinct vertical slot configurations. Ecol Eng 105:180-188

Sadhale N, Nene YL (2005) On Fish in Manasollasa (c. 1131 AD). Asian Agri-Hist 9:177-199

Saitoh K, Chen WJ, Mayden RL (2010) Extensive hybridization and tetrapolyploidy in spined loach fish. Mol Phylogenet Evol 56:1001-1010

Santos JM, Silva A, Katopodis C, Pinheiro P, Pinheiro A, Bochechas J, Ferreira MT (2012) Ecohydraulics of pooltype fishways: getting past the barriers. Ecol Eng 48:3850

Sarkar UK, Pathak AK, Lakra WS (2008) Conservation of freshwater fish resources of India: new approaches, assessment and challenges. Biodivers Conserv 17:24952511

Sarma D, Das R, Akhtar MS, Ciji A, Sharma NK, Singh AK (2016) Morpho-histological and ultra-architectural changes during early development of endangered golden mahseer Tor putitora. J Fish Biol 89:2038-2054

Saunders DL, Meeuwig JJ, Vincent AC (2002) Freshwater protected areas: strategies for conservation. Conserv Biol 16:30-41

Sen TK, Jayaram KC (1982) Mahseer fishes of India: a review. Rec Zool Surv India 39:1-34

Shahi N, Mallik SK, Sarma D (2014) Golden mahseer, Tor putitora - a possible candidate species for hill aquaculture. Aquac Asia 14:22-28

Sharma RC (1987) Aims and strategies of fisheries management for the Tehri dam reservoir in the Garhwal Himalaya, India. In DeSiva SS (ed) Proceedings. Reservoir fishery management and development in Asia. IDRC, Kathmandu, pp 145-153 
Sheaves M, Baker R, McLeod I, Abrantes K, Wani J, Barnett A (2016) The conservation status of Niugini black bass: a world-renowned sport fish with an uncertain future. Fish Manag Ecol 23:243-252

Shrestha TK (1997) The mahseer in the rivers of Nepal disrupted by dams and ranching strategies. The mahseer in the rivers of Nepal disrupted by dams and ranching strategies. Bimala Shrestha, Kathnandu

Shrestha TK (2002) Ranching mahseer (Tor tor and Tor putitora) in the running waters of Nepal. In: Cold water fisheries in the trans-Himalayan countries. FAO Fisheries Technical Paper 431, pp 297-300

Shrestha AB, Agarwal NK, Alfthan B, Bajracharya SR, Marechal J, van Oort B (eds) (2015) The Himalayan Climate and Water Atlas: Impact of climate change on water resources in five of Asia's major river basins. ICIMOD, GRID-Arendal and CICERO, pp 1-96

Smith LE, Khoa SN, Lorenzen K (2005) Livelihood functions of inland fisheries: policy implications in developing countries. Water Policy 7:359-383

Stensland S, Aas $\varnothing$ (2014) The role of social norms and informal sanctions in catch-and-release angling. Fish Manag Ecol 21:288-298

Sykes WH (1839) On the fishes of the Deccan. Proc Zool Soc Lond 6:157-165

Sykes WH (1841) On the fishes of the Dukhun. Trans Zool Soc Lond 2:349-378

Takahara T, Minamoto T, Yamanaka H, Do H, Kawabata ZI (2012) Estimation of fish biomass using environmental DNA. PLoS ONE 7(4):e35868

Talwar PK, Jhingran AG (1991) Inland fishes of India and adjacent countries. A.A. Balkema, Rotterdam, p 541

Theophilus E (2014) Headwater Extinctions-hydropower projects in the Himalayan reaches of the Ganga and the Beas: a closer look at fish and river ecosystems. South Asia Network on Dams, Rivers and People (SANDRP), Delhi. https://sandrp.files.wordpress.com/2018/03/headwa ter_extinctions221114.pdf. Accessed 13 Mar 2019

Thomas HS (1873) The Rod in India. Stolz, Mangalore

Thomsen PF, Kielgast JOS, Iversen LL, Wiuf C, Rasmussen M, Gilbert MTP, Orlando L, Willerslev E (2012) Monitoring endangered freshwater biodiversity using environmental DNA. Mol Ecol 21:2565-2573

Tripathi YR (1978) Artificial breeding of Tor putitora. J Int Fish Soc India 9:161

Tufts BL, Holden J, DeMille M (2015) Benefits arising from sustainable use of North America's fishery resources: economic and conservation impacts of recreational angling. Int J Environ Stud 72:850-868

Turner CR, Uy KL, Everhart RC (2015) Fish environmental DNA is more concentrated in aquatic sediments than surface water. Biol Conserv 183:93-102

TWFT (1984) Trans-world fishing team: Quest for a Legendary Fish. Dehra Dun, International Book Distributors

Ullah A (2015) Public private partnership in hydro-power development of India: prospects and challenges. J Bus Manag Soc Sci Res 4:190-201

Vidthayanon C, Pinder A (2018) Tor sinensis. The IUCN red list of threatened species 2018: e.T187891A126322879. http://dx.doi.org/10.2305/IUCN.UK.2018-2.RLTS. T187891A126322879.en. Accessed 13 Mar 2019
Vishwanath W, Dahanukar N, Pinder A., Harrison A (2018) Tor barakae. The IUCN red list of threatened species 2018: e.T168258A126322721. http://dx.doi.org/10.2305/ IUCN.UK.2018-2.RLTS.T168258A126322721.en. Acces sed 13 Mar 2019

Vörösmarty CJ, McIntyre PB, Gessner MO, Dudgeon D, Prusevich A, Green P, Glidden SE, Sullivan CA, Liermann CR, Davies PM (2010) Global threats to human water security and river biodiversity. Nature 467:555-561

Wagh GK, Ghate HV (2003) Freshwater fish fauna of the rivers Mula and Mutha, Pune, Maharashtra. Zoo's Print 18:977981

Walton SE, Gan HM, Raghavan R, Pinder AC, Ahmad A (2017) Disentangling the taxonomy of the mahseers (Tor spp.) of Malaysia: an integrated approach using morphology, genetics and historical records. Rev Fish Sci Aquac 25:171-183

Wildlife (1977) The monsters of Karnataka. Wildlife Journal of the Wildlife Association of South India (WASI), pp 1-8

Wilkes MA, Mckenzie M, Webb JA (2018) Fish passage design for sustainable hydropower in the temperate Southern Hemisphere: an evidence review. Rev Fish Biol Fish 28:117-135

Williams JG, Armstrong G, Katopodis C, Larinier M, Travade F (2012) Thinking like a fish: a key ingredient for development of effective fish passage facilities at river obstructions. River Res Appl 28:407-417

Wong JZ, Etoh S, Sujang AB (2009) Towards sustainable community-based fishery resources management: the Tagal system of Sabah, Malaysia. Secr Southeast Asian Fish Dev Center 7:18-27

World Bank (2012) Hidden harvest: the global contribution of capture fisheries. Report \# 66469-GLB. World Bank, Washington, DC, USA

World Bank. (2018) Population growth (annual \%). http://data. worldbank.org/indicator/SP.POP.GROW. Accessed 21Sept 2018

World Commission on Dams (2000) Dams and Development: A New Framework for Better Decision-making. Earthscan, London

Wu XW (ed) (1977) Cyprinid fishes of China, vol 2. Science and Technology Publishing House, Shanghai, pp 209-598 (in Chinese)

WWF-India (2013) Mahseer conservation in India: status, challenges and the way forward. In: Nautiyal P, Babu S, Behera S (eds) WWF-India. New Delhi, India, p 38

Yang L, Sado T, Hirt MV, Pasco-Vie E, Arunachalam M, Li J, Wang X, Freyhof J, Saitoh K, Simons AM, Miya M (2015) Phylogeny and polyploidy: resolving the classification of cyprinine fishes (Teleostei: Cypriniformes). Mol Phylogenet Evol 85:97-116

Zhou W, Cui GH (1996) A review of Tor species from the Lancangjiang River (Upper Mekong River), China (Teleostei: Cyprinidae). Ichthyol Explor Fres 7:131-142

Publisher's Note Springer Nature remains neutral with regard to jurisdictional claims in published maps and institutional affiliations. 